\title{
Godzina uczniów Jezusa (J 16,32; 18-19) okazją do objawiania się Mistrza ${ }^{1}$
}

\author{
The Hour of Jesus' Disciples (Jn 16:32; 18-19) \\ as an Opportunity for the Revelation of the Master
}

\section{ZBIGNIEW GROCHOWSKI}

Uniwersytet Kardynała Stefana Wyszyńskiego, Warszawa

zbigniewgrochowski@gmail.com, ORCID: 0000-0002-1785-5684

\begin{abstract}
Streszczenie: Pojęcie „godzina próby” w czwartej Ewangelii najczęściej kojarzy się z męką Pańską. Okazuje się, że jest to moment trudnego doświadczenia, jaki będą przeżywać także uczniowie Jezusa zarówno podczas pojmania Mistrza (por. J 16,32), jak i później, gdy przyjdą prześladowania chrześcijan (por. J 16,2.4.21). Niniejszy artykuł prezentuje sześć typów postaw uczniów Jezusa przedstawionych w „Męce Pańskiej” (J 18-19), ale także - aby nie zaniedbać chrystologii - pokazuje, w jaki sposób stają się oni przy tej okazji „lustrem” dla objawienia Jezusa. Chrystus objawia się bowiem nie tylko za pośrednictwem własnych verba et facta, lecz czyni to także dzięki interakcji ze swymi uczniami lub w zestawieniu (бúүкрıбıৎ) własnej postawy z ich zachowaniem. W ten sposób stają się oni locus theologicus objawienia Jezusa. Godzina uczniów staje się więc okazją, by objawienie Mistrza wybrzmiało jeszcze dobitniej i w sposób bardziej zrozumiały.
\end{abstract}

Słowa kluczowe: Ewangelia wg świętego Jana, narracja o Męce Pańskiej, uczniowie Jezusa, „godzina” Jezusa, „godzina” uczniów Jezusa, objawienie Jezusa

Abstract: The term "the hour of trial" in the Fourth Gospel is most often associated with the Passion of the Lord. The present work reminds us that Jesus' disciples lived through and reacted to this difficult and pivotal experience as well, both during the arrest of the Master (cf. Jn 16:32) and later, when the persecution of Christians comes (cf. Jn 16:2.4.21). This article presents six types of attitudes exhibited by Jesus' disciples as described in the Passion Narrative (Jn 18-19). In addition, from a Christological perspective, it demonstrates how the disciples' various responses become a "mirror" for Jesus' own revelation on this occasion. Christ gives his revelation not only through his own verba et facta, but also through interaction with his disciples, or in the juxtaposition (бúүкрıбı૬) of his own attitude with their behavior. In this way, they become the locus theologicus of Jesus' revelation. Thus the hour of the disciples becomes an occasion in which the revelation of the Master resounds even more forcefully and in a more understandable way.

Keywords: Fourth Gospel, Passion Narrative, discipleship, the hour of Jesus, the hour of Jesus's disciples, revelation of Jesus

1 Niniejszy artykuł w dużym stopniu nawiązuje do treści tekstu zatytułowanego „I discepoli di Gesù nell’ora della prova (Gv 18-19) come luogo di rivelazione del Maestro”, BibAn 3/1 (2013) 67-92, będącego zapowiedzią monografii Il discepolo di Gesù nellora della prova (Gv 18-19), luogo di rivelazione del Maestro (Studia Biblica Lublinensia 13; Lublin: Wydawnictwo KUL 2015) [ss. 556]. Po naniesionych poprawkach i gruntownej rewizji, stanowi jego aktualizację. Jego celem jest przybliżenie zaprezentowanych tam idei polskiemu czytelnikowi, dla którego język włoski może stanowić barierę nie do pokonania. 
Grecki rzeczownik $̋ \rho \alpha$ („godzina”) może być rozumiany dosłownie lub w przenośni. Wybierając spośród wszystkich ksiąg Pisma Świętego tę, w której słowo to występuje najczęściej - a jest nią czwarta Ewangelia (26 razy) ${ }^{2}$ - zauważa się, że jedynie w siedmiu przypadkach przyjmuje on znaczenie dosłowne, określając precyzyjną

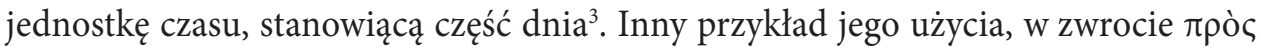
๘̈pav $(5,35)$, odnosi się do nieokreślonego, krótkiego czasu. Natomiast w pozostałych miejscach przybiera on wydźwięk mniej lub bardziej metaforyczny. Mówi o momencie ustalonym przez Boga ${ }^{4}$, o cierpieniach przeżywanych przez ludzi ${ }^{5}$, ale przede wszystkim traktuje on o męce (będącej jednocześnie uwielbieniem) Jezusa ${ }^{6}$, rozumianej jako "godzina” par excellence (zawsze z rodzajnikiem). Natomiast w J 19,27

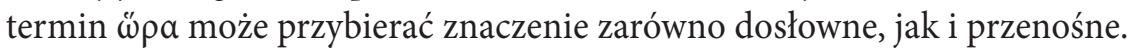

Nie brakuje artykułów i monografii badających to ostatnie metaforyczne znaczenie, czyli Janowy temat "godziny Jezusa”. Okazuje się jednak, że trudno jest znaleźć opracowania zajmujące się kwestią „godziny Jego uczniów” w czwartej Ewangelii.

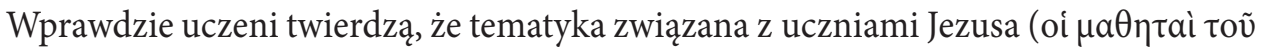

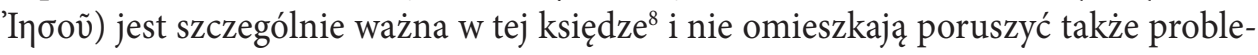
mu ich trudności w wierze czy nawet prześladowań czekających wspólnotę uczniów to jednak nie koncentrują swych badań na narracji męki Pańskiej, mimo że w J 16,32 wyraźnie zapowiedziane jest nadejście ich „godziny” jako współistniejącej z „godziną" Mistrza ${ }^{10}$. Egzegeci ci zajmują się raczej sprawą przyszłych cierpień wspólno-

Por. de La Potterie, La passion, 17-19.

Por. 1,$39 ; 4,6.52[$ bis $] .53 ; 11,9 ; 19,14$.

Por. $4,21.23 ; 5,25.28 ; 16,25$.

Por. 16,2.4.21.32.

Por. 2,$4 ; 7,30 ; 8,20 ; 12,23.27[$ bis $] ; 13,1 ; 17,1$.

Por. Ferraro, Ora, 300; idem, „Ora”, 203; idem, „Terminologia temporale”, 382; idem, Spirito, 135-139; Beutler, „Stunde”, 321; Schnackenburg, Wunder, 41; Moloney, „Ora”, 165; Zevini, „Ora”, 169; idem, „Ora storica”, 116; Morrison, „Hour of Destress”, 590; Feuillet, „Heure”, 7; Hanimann, „Heure”, 546; Destro Pesce, Giovanni, 6; Galizzi, „Ora”, 217; Daise, Feasts, 153-170.

8 Brown, „Other Sheep”, 17: „The Fourth Gospel (...) gives virtually no attention to the category of «apostle» and makes «disciple» the primary Christian category”. Mówiąc o „uczniach”, intencjonalnie pomijana jest także koncepcja „Dwunastu”, która nie stanowi dla czwartego ewangelisty szczególnie ważnego zagadnienia: termin $\delta \omega ́ \delta \varepsilon \kappa a$ występuje tylko w 6,67.70.71 i 20,24 i oznacza krąg osób najściślej związanych z Jezusem; por. Collins, These Things, 80-86; Borrel, „Els Dotze”, 301. Tematykę „uczniów” w Ewangelii według świętego Jana - począwszy od lat siedemdziesiątych XX w. - podejmują m.in. następujące opracowania: Moreno, „Discípulo”, 269-311; de Jonge, Jesus; Siker-Gieseler, „Disciples and Discipleship”, 199-227; Culpepper, Anatomy, 115-125; Riesner, Jesus als Lehrer; Köstenberger, „Jesus as Rabbi”, 97-128; Pesce, „Discepolato”, 351-389; Coulot, Jésus et le disciple, 195-246; Manns, „Encore une fois” 29-52; du Rand, „Discipleship”, 311-325; Gloer, „Come and see”, 269-301; Vignolo, Personaggi; Van der Merwe, „Discipleship”, 339-359; Beck, Discipleship; Köstenberger, Mission; Martín-Moreno, Personajes; Marchadour, Personaggi; Chennattu, Discipleship; Kl’uska, Uczeń; Klink, Sheep.

9 Por. Schnackenburg, „Jünger, Gemeinde, Kirche im Johannesevangelium”, 231-245; Brown, Community, 40-43; 71-88; Segovia, „Discipleship”, 76-102.

10 J 16,32: „Oto nadchodzi godzina, a nawet już nadeszła, że się rozproszycie - każdy w swoją stronę, a Mnie zostawicie samego. Ale Ja nie jestem sam, bo Ojciec jest ze Mną”. Ferraro, Ora, 302, pisze: „l'«w̋pa» della 
ty Janowej, zgromadzonej wokół ewangelisty pod koniec I w., związanych z birkat hamminim (= „błogosławieństwo [w sensie: przekleństwo] odstępców”), znajdującą swoje (mniej lub bardziej poświadczone historycznie) echo w „wykluczeniu z Synagogi", trzykrotnie wzmiankowanym $\mathrm{w}$ czwartej Ewangelii ${ }^{11}$. Wprawdzie wielu uczonych neguje fakt, iż Sitz im Leben wspólnoty Janowej stanowiła decyzja synodu w Jabne o eliminowaniu chrześcijan z grona wyznawców judaizmu ${ }^{12}$, jednak ta "tradycyjna" opinia nie powinna być całkowicie odrzucona (lub przynajmniej birkat hamminim powinna być uwzględniana w kontekście Janowego ảmoøvvá $\gamma \omega \gamma o \varsigma)$, ze świadomością istnienia rosnącego wówczas napięcia między pierwotnym Kościołem a Synagogą ${ }^{13}$.

Zasadniczym celem niniejszego studium jest uzupełnienie zarysowanego powyżej braku analiz Janowego zagadnienia „godziny uczniów Jezusa”. Artykuł skoncentruje się zatem na rozdziałach 18-19 czwartej Ewangelii, w których ma miejsce realizacja zapowiedzi momentu próby, której będą poddani uczniowie Chrystusa, zgodnie ze słowami Mistrza wyrażonymi podczas Ostatniej Wieczerzy $(16,32)$.

Realizacja powyższego podstawowego celu studium dokona się poprzez analizę dwóch kwestii. Pierwsza, korespondująca z początkiem tytułu („Godzina uczniów Jezusa..."), będzie dotyczyć analizy postaw uczniów Chrystusa przybranych podczas męki Pańskiej. Omówieniu przyświecać będzie świadomość faktu, iż chrześcijanie wszystkich epok nierzadko w swym życiu przechodzą rozmaite próby, bądź to czysto zewnętrzne (ucisk i prześladowanie), bądź to przybierające charakter wewnętrzny (np. walka duchowa). We wszystkich tych sytuacjach poddawana jest weryfikacji prawda o autentyczności bycia uczniem Jezusa. Dlatego postawa towarzyszy Chrystusa, przedstawiona w J 18-19 i poniżej esencjonalnie omówiona, będzie mogła posłużyć każdemu chrześcijaninowi jako model godny naśladowania w życiu wiary lub jako antyprzykład - celem odżegnania się od niej, jeśli sprzeciwiałoby się to idei wiernego trwania przy swym Mistrzu. Dzięki temu orędzie ewangeliczne stanie

dispersione degli apostoli coincide con l'«üpa» della passione di Gesù". Wprawdzie jeszcze dwie pozycje (Carroll - Green, „Death of Jesus”, 82-109; Senior, „Death of Jesus and Discipleship”, 234-255) przywołują temat uczniów Jezusa w kontekście męki ich Mistrza, ale nie definiują tego motywu jako „godzina uczniów".

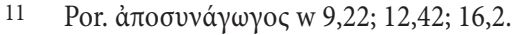

12 Por. Schoeps, Jewish Christianity, 33; Sigal, „An Inquiry”, 93; Kimelman, „Birkat Ha-Minim”, 226-244; Katz, „Issues”, 66; van der Horst, „The Birkat ha-Minim”, 111; Wilson, Related Strangers, 180; Lieu, „Temple", 51; Hare, The Theme, 55; Teppler, Birkat haMinim, 354; Jacobs, ,Jews and Christians”, 178.

13 Por. Manns, „Lévangile de Jean”, 47-92 (zwł. 72, 88, 91); Horbury, „The Benediction”, 59-61; idem, „Early Christians”, 296-317; Flusser, „The Jewish-Christian”, 617-634, 635-644; Segalla, Evangelo e vangeli, 355; Kl’uska, Uczeń, 109-111, 275-276, 416; Zumstein, L’évangile, 263; Wróbel, „Znaczenie formuly”, 65-80; Mariano, Tetelestai, 16-17, przyp. 7; Crimella, „Dal maestro alle comunità, 159; Rosik, „Nazarejczycy czy heretycy?”, 1275-1288; Chrostowski, Między Synagogą a Kościołem, 11-18; Rosik, Kościół a Synagoga, 374-375: „pisma Janowe (...) są jego [= rozbratu Kościoła i Synagogi] świadectwem (...) [C]hrześcijańska polemika z judaizmem rysuje się na kartach pism przypisywanych Janowi apostołowi w sposób niezwykle ostry". 


\section{ZBIGNIEW GROCHOWSKI}

się użyteczne dla współczesnych uczniów Jezusa, tak jak było nim dla chrześcijan żyjących w I w., kiedy doznawali represji zarówno ze strony Synagogi, jak i Imperium Rzymskiego.

Druga kwestia, znajdująca swoje odzwierciedlenie w końcowym członie tytułu („...okazją do objawiania się Mistrza”) dotyczy powiązania aspektu eklezjologicznego z chrystologicznym. Skupienie uwagi jedynie na uczniach Jezusa oznaczałoby zaniedbanie jakże ważnej, podstawowej dla Ewangelii, perspektywy chrystologicznej. Dzięki zastosowaniu ciekawego spojrzenia, zaproponowanego przez Alaina Marchadoura oraz Gail R. O'Day, podjęta będzie próba odkrycia w postawie uczniów ich funkcji służebnej względem Jezusowego objawienia. Okazuje się, że Chrystus przemawia nie tylko za pomocą własnych verba et facta, lecz komunikuje swoje orędzie także za pośrednictwem zachowania, reakcji czy postaw przybieranych przez spotykające się z Nim osoby. Innymi słowy, Jezusa można poznawać przynajmniej dwojako: bezpośrednio, zgłębiając treść Jego słów i gestów czy też stosowanych przez Niego (lub przypisywanych $\mathrm{Mu}$ ) tytułów chrystologicznych, lub pośrednio, poprzez analizę postawy bohaterów narracji, którzy swoją odpowiedzią (lub jej brakiem), wierną obecnością (lub np. zdradą), takim czy innym słowem lub gestem wzmacniają objawienie Jezusa, „odbijające się" na ich osobach jak w lustrze ${ }^{14}$. Dzięki temu także uczniowie biorący udział w "godzinie" swego Mistrza mogą stać się locus theologicus Jego objawienia ${ }^{15}$. Tytuł niniejszego artykułu wyraża tę prawdę za pomocą nieco bardziej przystępnego pojęcia, jakim jest słowo „okazja”. Konkludując, intencją artykułu będzie przyjrzenie się poszczególnym typom zachowania się uczniów podczas męki Jezusa opowiedzianej przez czwartego ewangelistę oraz to, w jaki sposób pełnią oni przy tej okazji rolę „lustra” dla objawienia swego Mistrza ${ }^{16}$.

W niniejszym artykule zastosowane będzie synchroniczne podejście do tekstu. Wykorzystane będą niektóre elementy metody narracyjnej. Swoistym novum będzie między innymi przywołanie zasady first-time reader podczas próby identyfikacji tajemniczego „innego ucznia” $(18,15-16)$ oraz wykorzystanie techniki telling \& showing przy scharakteryzowaniu Nikodema jako ucznia Jezusa (19,38-42). Nie zabraknie także elementów analizy retorycznej, mających na celu przede wszystkim rozpoznanie danej figury retorycznej, określenie jej nazwy oraz zdefiniowanie funkcji pełnionej przez nią w tekście.

Struktura opracowania prezentuje się następująco. Korpus pracy, umieszczony pomiędzy niniejszym wprowadzeniem a zakończeniem, podzielony będzie na sześć części, odpowiadających typom uczniów Jezusa, zidentyfikowanym w J 18-19.

\footnotetext{
14 Por. Marchadour, Personaggi, 7.

15 Do tego pojęcia nawiązuje z kolei Gail R. O’Day (Revelation in the Fourth Gospel, 94, 96), pisząc 0 "the locus of revelation”, z sugestią, że czytelnik Ewangelii poznaje objawienie Jezusa (również) dzięki analizie postawy uczniów (a zwłaszcza zdarzającego się u nich misunderstanding).

16 Uwaga natury technicznej: odsyłacze biblijne pozbawione skrótu nazw ksiąg Pisma Świętego zawsze będą się odnosić do Ewangelii wg św. Jana.
} 
W każdej części, zgodnie z dwojakim celem artykułu, najpierw będzie miała miejsce prezentacja postawy poszczególnych uczniów, a potem - po wizualizacji graficznego znaku „***" (wciąż w ramach tego samego punktu) - będzie powiedziane, w jaki sposób Jezus objawia się przy „okazji” takiego, a nie innego ich zachowania. W niektórych paragrafach będzie dodatkowo zasygnalizowane, w jaki sposób Jezus objawia się bezpośrednio, a więc poprzez własne słowa i czyny. Wówczas zachowanie uczniów będzie służyło potwierdzeniu (i wzmocnieniu) Jezusowego objawienia.

\section{Uczniowie jako grupa (oi $\mu a \theta \eta \tau a i)$}

W narracji męki Pańskiej uczniowie występują jako zwarta grupa jedynie w pierwszej perykopie (18,1-14). Wymienieni są na jej początku jako podmiot zbiorowy, działający razem z Jezusem. Mowa tu o ich wspólnym wyjściu z Wieczernika, wejściu do ogrodu oraz o ich częstych spotkaniach w tym miejscu w przeszłości (18,1-2). Jednak chociaż rzeczownik $\mu a \theta \eta \tau$ đá („uczniowie") nie występuje już więcej w perykopie, nie można wątpić, że uczniowie byli obecni także podczas dialogów i epizodów dziejących się w ogrodzie nieco później. Jako że w 18,8 Jezus domaga się zezwolenia na spokojne odejście uczniów oraz w 18,10-11 swoją rolę odegrał jeszcze Szymon Piotr, należy stwierdzić, że uczniowie byli świadkami wszystkich zdarzeń mających miejsce w ogrodzie, aż do momentu pojmania Jezusa.

Początkowo ich obraz jest pozytywny. Ewangelista podkreślił wierną i posłuszną wędrówkę uczniów śladami Mistrza, stwierdzając aż trzy razy, że Jezus ,wyszedł ze swoimi uczniami (...) wszedł On i jego uczniowie (...) Jezus często spotykał się tam ze swoimi uczniami” (18,1-2). Więź przyjaźni, do której już wcześniej zaprosił ich Pan (por. 15,14-15), została potwierdzona troską, z jaką Mistrz próbował zadbać o ich przyszły los. Celem drugiego w tej perykopie pytania skierowanego do kohorty oraz sług żydowskich (por. „Kogo szukacie?” w 18,8) było zagwarantowanie uczniom nietykalności fizycznej ${ }^{17}$. Jednak uczniowie - choć w odpowiedzi Jezusa zawarta była domyślna sugestia, aby mogli sobie odejść - nie zachowali się w sposób godny pochwały. Mogli przecież ostatecznie pozostać z Mistrzem, kontynuując swą wędrówkę Jego śladami, aż po zadeklarowaną wcześniej gotowość śmierci wraz z Nim. Wręcz

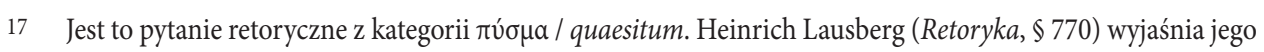
znaczenie, zestawiając je z pytaniem innego typu: „Wielu teoretyków odróżnia quaesitum ( $\pi \dot{\sigma} \sigma a$ ) «pytanie» od interrogatio «zapytanie». Różnicę dostrzega się w tym, iż jedynie możliwą odpowiedzią na interrogatio jest «tak» lub «nie», podczas gdy quaesitum wymaga bardziej szczegółowych odpowiedzi”. Inna definicja,

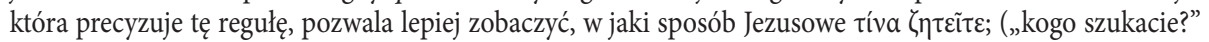

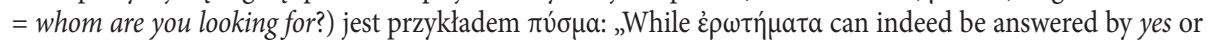

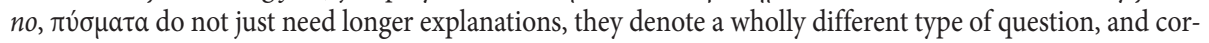
respond exactly to what in grammars of English are called wh-questions” (Rijksbaron, „A Question”, 733). 


\section{ZBIGNIEW GROCHOWSKI}

przeciwnie, zniknęli ze sceny ${ }^{18}$. Ta smutna konkluzja została precyzyjnie przepowiedziana przez Jezusa: „Oto nadchodzi godzina, a nawet już nadeszła, że się rozproszycie - każdy w swoją stronę, a Mnie zostawicie samego" (16,32).

Harmonijny obraz uczniów, zaprezentowany w 18,1-2 - zakłócony jedynie obecnością „byłego ucznia”, czyli Judasza Iskarioty $(18,2-3)^{19}$ - przekształcił się w gorycz finalnej sceny tej perykopy: w 18,12-14 nie wspomina się już „Jego uczniów”. Mówi się natomiast o Jezusie otoczonym przez uzbrojonych ludzi, aresztowanym i prowadzonym do arcykapłanów. Uczniowie, którzy w Getsemani byli tak bardzo zjednoczeni z Mistrzem - w momencie gdy przybywa kohorta i strażnicy żydowscy, a ich Pan odważnie stawia czoło godzinie swojej próby - nie są w stanie podołać ich własnej „godzinie”. Realizuje się smutna zapowiedź Jezusa o rozproszeniu uczniów i opuszczeniu przez nich swojego Mistrza $(16,32)$.

Uważna lektura chrystologiczna perykopy 18,1-14 prowadzi do wniosku, że Jezus jest w niej ukazany jako Pan sytuacji. Jego słowa i czyny w jasny sposób podkreślają ten aspekt Jego tożsamości: ewangelista mówi o wiedzy Jezusa na temat faktów mających wydarzyć się w przyszłości $(18,4.9)$; prezentuje Go jako wyjątkowego Proroka, przypisując Jego słowom autorytet identyczny z tym, jaki posiada Pismo Święte

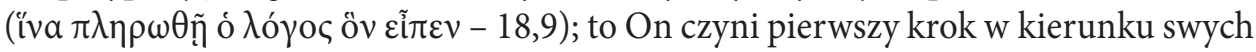
przeciwników $(18,4)$ i rozpoczyna z nimi dialog $(18,4.7)^{20}$; po upadku oddziału na ziemię jako reakcji na pełne mocy słowo Jezusa $(18,6)$ - On sam, zamiast wykorzystać okazję, aby uciec - pozostaje na swoim miejscu i kontynuuje zadawanie pytań, przejawiając troskę o bezpieczeństwo uczniów (18,7-9). Zwracając się do kohorty, nie przedstawia „grzecznej prośby”, lecz wydaje polecenie przypominające wojskowy rozkaz ${ }^{21}$. Wynika stąd również, że nie poszedł On do ogrodu, aby w dalszym ciągu się ukrywać (por. 11,53-54), lecz - wręcz przeciwnie - aby wystawić się swoim oprawcom na cel ${ }^{22}$ : jest w pełni zdecydowany, aby „pić kielich” (metafora męki, którą powinna zakończyć się misja powierzona Mu przez Ojca - 18,11)²3; jest gotów umrzeć

18 Czwarta Ewangelia nie wspomina „ucieczki” uczniów. Zauważa się jedynie ich nieobecność w dalszej części męki Pańskiej.

19 W dalszej części podane będzie uzasadnienie zdefiniowania Judasza jako eks-ucznia.

20 U św. Jana brakuje epizodu „pocałunku Judasza”, którego celem było zidentyfikowanie osoby Mistrza (Mk 14,44-45; Mt 26,48-49; Łk 22,47-48); w czwartej Ewangelii to sam Jezus prezentuje się wobec tych, którzy przybyli, aby Go aresztować.

21 Por. Kręcidło, Honor $i$ wstyd, 306.

22 Nie ulega wątpliwości, że Jezus wiedział, iż Judasz znał miejsce, w którym Mistrz spotykał się ze swoimi uczniami (por. 18,2). Jezus wiedział też o wszystkim, co miało na Niego przyjść (por. 18,4).

23 Brakuje w narracji Janowej sceny agonii, zrelacjonowanej przez synoptyków (zob. zwłaszcza Jezusowe wołanie „Ojcze, jeśli to możliwe, oddal ode mnie ten kielich” - Mt 26,39; Mk 14,36; Łk 22,42): w czwartej Ewangelii kielich jest przez Jezusa w pełni zaakceptowany. 
za „wszystkie rozproszone dzieci Boże” (por. 11,50-51; 18,14); jest Dobrym Pasterzem, który dobrowolnie „oddaje życie za swoje owce” (10,17-18), czyli uczniów ${ }^{24}$.

Również w ostatniej części perykopy Jezus - pomimo wrażenia bierności - w dalszym ciągu przejawia swoją suwerenność (18,12-14). Wyraźny jest kontrast między Chrystusem, który objawia się w swoim trzykrotnym $\dot{\varepsilon} \gamma \omega \dot{~ \varepsilon i ̉ \mu t, ~ w ~ c z a s i e ~ t e r a z ́ n i e j-~}$ szym (,ja jestem” - 18,5.6.8), a Annaszem i Kajfaszem z ich trzykrotnym $\tilde{\eta} v$, w czasie przeszłym („był” - 18,13-14). Ponadto niewykluczone, że ewangelista czyni aluzję do ăqêdāh / związania Izaaka (por. Rdz 22,9) oraz Łazarza (por. 11,44), zapowiadając zwycięstwo Jezusa nad śmiercią (zwłaszcza, że tylko w czwartej Ewangelii jest On ukazany jako „Związany” już w scenie pojmania - 18,12) ${ }^{25}$. W świetle ukazanej wcześniej postawy Jezusa należy stwierdzić, że w końcowym etapie wydarzeń z Ogrójca (18,12-14) Chrystus nie tyle jest pojmany, ile pozwala się zaaresztować i poprowadzić do arcykapłanów. Jezus nie zachowuje się jak bierna ofiara, pogodzona ze swoim losem, lecz działa w sposób aktywny, gotów stawić czoło „godzinie, która nadeszła” $(13,1 ; 17,1)$.

Zostało wyżej nakreślone, w jaki sposób Jezus objawił w ogrodzie swoją suwerenność za pomocą własnych słów i czynów. Rodzi się pytanie: czy uczniowie, przybierając na początku postawę godną pochwały, a potem zachowując się bez honoru, „uciekając, każdy w swoją stronę” (16,32), wnoszą jakiś wkład w to zagadnienie?

Pozytywnie. W Ewangelii Janowej wyraźnie przedstawiono posłuszną i wierną wędrówkę uczniów za Jezusem. Jak zostało już wyżej zauważone, aż trzykrotnie jest wspomniane, że od Wieczernika po Ogrójec Jezus $\dot{\varepsilon} \xi \tilde{\eta} \lambda \theta \varepsilon v(\ldots) \varepsilon \dot{i} \sigma \tilde{\eta} \lambda \theta \varepsilon v(.$.

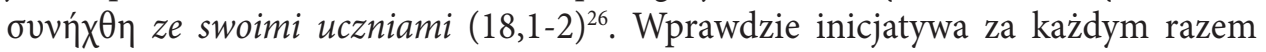
przynależała do Jezusa, ale uległość uczniów i pokorne podążanie Jego śladem potwierdziły autorytet Mistrza oraz wyeksponowały tę prawdę. Nie tylko zatem wobec swoich przeciwników (18,4-14), lecz także w relacji do swoich uczniów (i dzięki ich postawie) Jezus manifestuje swoją suwerenność oraz bycie Panem sytuacji. To On wyznacza drogę, ale dzięki uczniom wyraźniej widać, że rzeczywiście trzeba i warto pójść tym szlakiem za swym Mistrzem.

Negatywnie. Zakończenie perykopy 18,1-14 nie wspomina już uczniów. Zgodnie z przewidzeniem Jezusa (16,32) zostawili oni Mistrza na pastwę losu oraz woli uzbrojonych przybyszów. Ale nawet fakt zniknięcia apostołów ze sceny zaistniał, w pew-

24 Por. Grochowski, „Dobry Pasterz”, 141-176.

25 Mk 15,1 i Mt 27,2 mówią o Jezusie „Związanym” dopiero później, w kontekście procesów żydowskiego i rzymskiego.

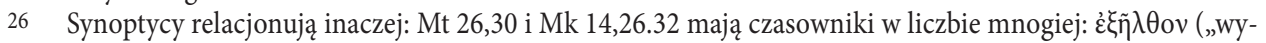

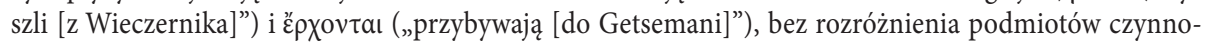
ści. Wprawdzie Mt 26,36 oraz Łk 22,39 wskazują już na inicjatywę Mistrza, ale czwarta Ewangelia - dzięki trzykrotnemu rozróżnieniu „Jezus” i „uczniowie” - wyraża tę prawdę dobitniej. Trzeba to przyznać

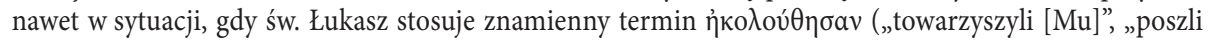
[za Nim])". 


\section{ZBIGNIEW GROCHOWSKI}

nym sensie, z inicjatywy Chrystusa. Mówiąc zdecydowanym głosem do oprawców „odpuście / pozwólcie im odejść” (18,9), Jezus zadbał o nietykalność fizyczną swoich uczniów, pozostawiając im swobodę w podjęciu decyzji: pozostać przy Mistrzu czy ratować się odwrotem ${ }^{27}$. Jezus objawia się tu jako dawca życia, który - zgodnie z planem Ojca - ma w zasięgu ręki zarówno wieczne zbawienie uczniów (18,9; por. 6,39; 10,28-29; 17,12), jak i ich doczesne bezpieczeństwo $(18,8)$. Manifestuje się przy tym jako Pan sytuacji, który wie o mającym nadejść rozproszeniu uczniów $(16,32)$, ale który jednocześnie w pełni respektuje ich wolność. Można przypuszczać, że Jezus wolałby, aby uczniowie pozostali przy Nim „na dobre i na złe”. Swoim słowem jednak w taki sposób „kieruje” dziejącymi się wydarzeniami, aby uczniowie nie popadli w rozpacz, gdy przyjdzie im później przeżywać wyrzuty sumienia związane z pozostawieniem Jezusa w rękach przeciwników.

\section{Judasz Iskariota}

Postać Judasza została wyżej określona mianem eks-ucznia. Ten specyficzny aspekt jego tożsamości uwydatnia figura retoryczna év $\theta u ́ \mu \eta \mu \alpha$, obecna w 18,2, gdzie jest powiedziane, iż Judasz „znał [to] miejsce, gdyż Jezus często spotykał się tam ze swoimi uczniami"28. To krótkie stwierdzenie podsumowuje działalność Jezusa prowadzoną w Jerozolimie. Podkreśla przy okazji rolę, jaką w formacji uczniów odegrał ten ogród (kojarzony zazwyczaj [niesłusznie] tylko z agonią Jezusa). Uzmysławia również, że w spotkaniach ze swym Mistrzem brał udział także Judasz. Jednocześnie stwierdzenie obecne w 18,3, iż Judasz przybył do Ogrójca z uzbrojonym oddziałem dowodzi, że nie przywędrował on tam wraz z pozostałymi uczniami. Jest rzeczywiście byłym uczniem, związanym w tym momencie już bardziej z przeciwnikami Mistrza, zdecydowanymi Go zgładzić.

Prezentacja postawy Judasza ukazuje jego stopniowe przechodzenie z jednej strony na drugą i przybiera postać figury amplificatio per incrementum. Oznacza ona „sukcesywną enumerację pogarszających się okoliczności”29. Ten, który wcześniej był uczniem Jezusa $(18,2)$, potem - jako Jego zdrajca ${ }^{30}$ - towarzyszył kohorcie przybyłej

27 Akt ucieczki wyraźnie wspominają Mk 14,50 i Mt 26,56.

28 'Ev $\theta \dot{u} \mu \eta \mu \alpha$ / ratiocinatio jest niekompletną formą sylogizmu (por. Lausberg, Retoryka, \$ 371). W naszym przypadku elementem przemilczanym i domyślnym argumentacji jest to, że on przynależał do grona uczniów. Figura ta służy w 18,2 sformułowaniu i jednocześnie wyjaśnieniu pojęcia eks-uczeń. Pominięcie

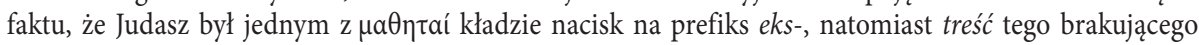
elementu wnioskowania wyraża prawdę o tym, że wcześniej był on jednym z uczniów.

29 Lausberg, Retoryka, $\$ 403$.

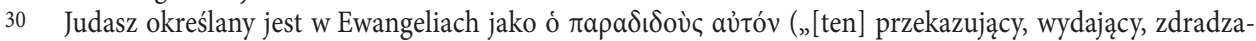

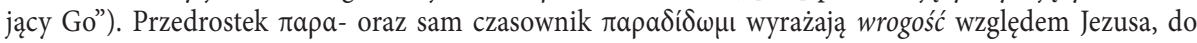
którego odnosi się zaimek aủtóc (por. Buscemi, L’uso delle preposizioni, 84). 
do ogrodu $(18,3)^{31}$, by na koniec w pełni się z nią zespolić w akcie wspólnego upadku na ziemię (18,5-6). Punktem kulminacyjnym crescendo jest definitywne przejście z jednej wspólnoty do drugiej: Judasz, który wcześniej wraz z innymi uczniami spo-

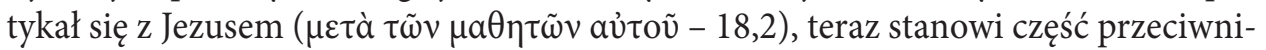

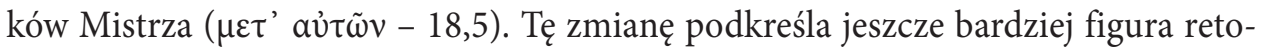
ryczna homoeoprophoron: zauważa się częste powtórzenie spółgłoski $\tau$ w sekwencji

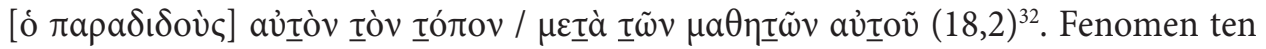
ukazuje ewidentny paradoks. Podczas gdy obie grupy wyrazów, obecne w jednym wersecie, łączy zjawisko fonetyczne, kontrastuje je jednocześnie semantyka: ten, który właśnie stał się zdrajcą Mistrza, nieco wcześniej był „z Jego uczniami”.

Amplificatio per incrementum może przybrać charakter rosnący lub malejący (amplificandi vel minuendi species) ${ }^{33}$. Podczas gdy w 18,2-5 została zidentyfikowana pierwsza z nich, w dalszej części narracji daje się zauważyć amplificatio drugiego typu. Polega ona na tym, że zdrajca, który wskazał zbrojnemu oddziałowi lokalizację Ogrójca i nawet stał się jego częścią, ostatecznie ... zniknął ze sceny. Perykopa 18,1-14 kończy się stwierdzeniem, że kohorta jako swojego dowódcę ma "trybuna” $(18,12$; por. 18,3$)$, z dużym prawdopodobieństwem, że także strażnicy wysłani przez arcykapłanów i faryzeuszów mają swego przełożonego w osobie Malchusa $(18,10)^{34}$. Wynika stąd, że Judasz, który sprawiał wrażenie bycia kimś ważnym dla Rzymian i przywódców żydowskich, ostatecznie nie przynależy już ani do uczniów Jezusa, ani do ekipy przybyłej do Ogrójca. Znika definitywnie ze sceny czwartej Ewangelii.

W jaki sposób objawia się Mistrz na swoim eks-uczniu? Zanim zostanie podana odpowiedź na to pytanie, konieczne jest dostrzeżenie, że w 18,1-14 - oprócz suwerenności Jezusa - podkreślona jest mocno przez ewangelistę także prawda o boskiej naturze Chrystusa. Celem pierwszego pytania skierowanego przez Jezusa do przeciwników ${ }^{35}$ było spowodowanie, aby kohorta i strażnicy żydowscy wypowiedzieli Jego imię, tak

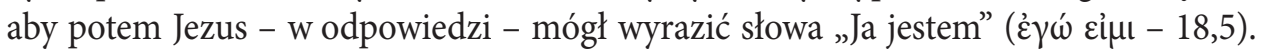
Z jednej strony oznaczają one Jego zwykłą autoidentyfikację (= „Ja jestem [tym Jezusem, którego szukacie]”), z drugiej - stają się narzędziem objawienia bóstwa Chrystu-

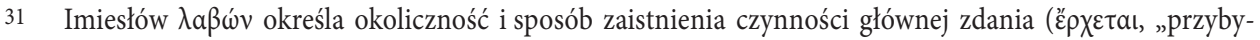
wa”) i odpowiada przyimkowi „z” (czyli tłumaczymy raczej „przybywa $z$ kohortą...”, a nie „wziąwszy kohortę...”). Taka interpretacja imiesłowu $\lambda a ß \omega ́ v$ pozwala wyczuć istniejące jeszcze odróżnienie Judasza od pozostałych członków oddziału; por. Blass - Debrunner - Rehkopf, Grammatik, $₫ 419,1^{1}$; Viteau, Étude, $\$ 309$ ac; Sabbe, „The Arrest of Jesus”, 212; Sanders - Mastin, A Commentary, 382, przyp. 2.

32 Lausberg, Retoryka, $₫ 975$ : „Homoeoprophoron jest częstym powtarzaniem tej samej spółgłoski (...) w sekwencji kilku słów".

33 Por. Lausberg, Retoryka, $₫ 402$.

34 Por. Witczyk, „Historia”, 228.

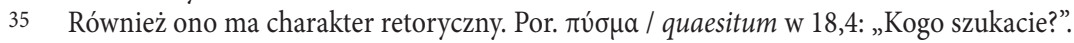




\section{ZBIGNIEW GROCHOWSKI}

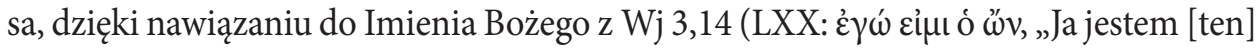
Będący”) oraz do uroczystej formuły ănî hû’ tekstu masoreckiego (,ja [jestem] nim) ${ }^{36}$.

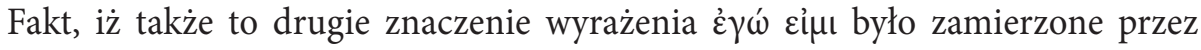
czwartego ewangelistę, potwierdza dalszy ciąg narracji: „cofnęli się i upadli na ziemię" $(18,6)$. Jest to typowa reakcja czlowieka na teofanie obecne w ST ${ }^{37}$. Ten gest, zupełnie nieoczekiwany, zawiera dwa paradoksy: pierwszy polega na tym, że uzbrojona grupa ludzi powalona jest na ziemię przez jednego bezbronnego człowieka, drugi zaś wynika z połączenia tej reakcji z faktem, że przynależy do niej także Judasz. Nie bez znaczenia jest w tym miejscu nota ewangelisty, która (pozornie) zakłóca (i opóźnia) narrację, ale która w rzeczywistości jest bardzo ważna dla zrozumienia treści opowiadania, że mianowicie „również i Judasz (...) stał między nimi” $(18,5)$. Był tam zatem obecny także ów były uczeń, co oznacza, że w skład zbiorowego podmiotu

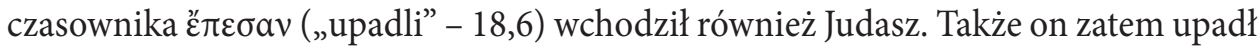
na ziemię u stóp Jezusa, potwierdzając - jako Żyd wyedukowany w Pismach (w od-

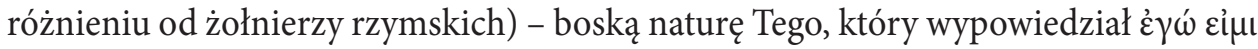
/ 'ănî hû.' Wyraził on jednocześnie (oczywiście niedobrowolnie) - wraz z przedstawicielami władzy świeckiej i religijnej - swój hołd wobec Tego, którego właśnie zdradzał ${ }^{38}$. Obecność Judasza - wprawdzie eks-ucznia, ale który na pewno pamiętał część komentarzy Mistrza na temat Prawa, Proroków i Pism - stała się locus theologicus, czyli okazją, dzięki której autoidentyfikacja Jezusa może być rozumiana jednocześnie jako samoobjawienie w kontekście teofanii ST.

\section{Szymon Piotr}

To kolejny uczeń (i jedyny oprócz Judasza) nazwany po imieniu w pierwszej części męki Pańskiej (18,1-27). Występuje w trzech odsłonach: w pierwszej perykopie $(18,1-14)$ jest jednym z uczniów (por. 18,1-2.10-11), który uderza mieczem sługę

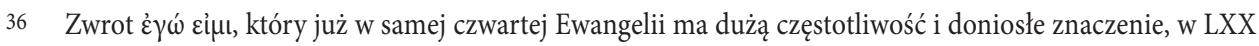
koresponduje niejednokrotnie $\mathrm{z}$ wyrażeniem 'ănî hû̀. W niemal wszystkich tych przypadkach podmiotem czynności jest YHWH (por. Pwt 32,39; Iz 41,4; 43,10; 46,4; 48,12; 52,6 [zob. ponadto Iz 43,25; 51,12, gdzie

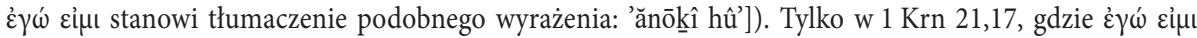
również stanowi przekład 'ănî hû̀, ma miejsce emfatyczna deklaracja człowieka, konkretnie: króla Dawida.

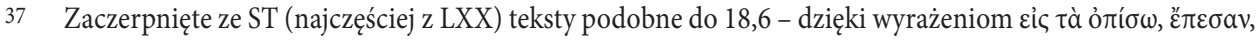

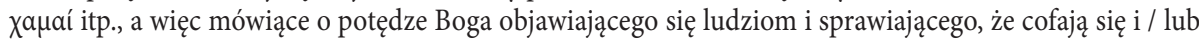
upadają na ziemię - są następujące: Wj 34,8; Joz 5,13-15; Ez 1,28; 43,3; 44,4; Dn 2,46; 8,18; 10,9; Hi 1,20; Ps 26,$2 ; 34,4 ; 39,15 ; 55,10 ; 69,3-4 ; 70,13 ;$ Iz 8,14-15; Jr 46,6.

38 Sugerowane przez Stanisława Mędalę oraz Rinaldo Fabrisa „przerażenie i dezorientacja” Judasza oraz towarzyszących mu osób - z czym niniejszy artykuł nie zamierza polemizować - nie stoi w sprzeczności ze stwierdzeniem, że ten byly uczeń (wraz z kohortą i wysłannikami arcykapłanów) oddał hołd Jezusowi. Wielki stownik języka polskiego (Dubisz [red.], s.v., II, 55) definiuje „hołd” jako „uroczysty akt uległości składany zwycięskiemu lub potężniejszemu władcy przez słabszego". Por. także Fabris, Giovanni, 694; Mędala, Jan, 186-187. 
arcykapłana, natomiast w drugiej $(18,15-27)$ działa już w odosobnieniu, odpowiadając przecząco na trzy pytania, postawione mu w dwóch narracyjnych sekcjach (18,16-18.25-27).

Zdumiewa to, że człowiek, którego jako jedynego spośród uczniów Jezus określił znamiennym przydomkiem „Skała” ( $\sigma \grave{v} \kappa \lambda \eta \theta \eta ் \emptyset n ~ K \eta \varphi \tilde{a} \varsigma-1,42$ ); ten, który w imieniu wszystkich uroczyście wyznał wiarę w Jezusa jako „Świętego Boga” (6,68-69); ten, który w swych gwałtownych reakcjach przechodził z jednej skrajności w drugą (najpierw - z pokory - wzbraniając się przed obmyciem mu nóg przez Pana $[13,6.8]$, by za chwilę - z pragnienia posiadania pełnego udziału z Jezusem - prosić o obmycie całego ciała [13,9]); w końcu ten, który obiecywał oddanie życia za Mistrza $(13,37)$ ... tak niefortunnie przeżył godzinę swojej próby, że przybrała ona posmak gorzkiej ironii i paradoksu: uczeń, który chciał uratować Jezusa z rąk oprawców (18,10-11), niewiele później wyparł się tego, że był z Nim w ogrodzie $(18,26-27)$ i przynależy do grona Jego wyznawców $(18,17.25)$.

Uderzenie mieczem. Czyn ucznia polegał na stawieniu oporu przemocy, aczkolwiek również przy użyciu fizycznej siły. Zdawał się on być godnym pochwały z racji odwagi i dobrej intencji, lecz Mistrz surowo zganił ucznia. Piotr nie tylko zadał drugiemu człowiekowi ranę i cierpienie, ale wykazał się też niezrozumieniem Bożego planu zbawienia (18,11b). Z drugiej strony kategoryczne słowa Jezusa nie zdołały powstrzymać Piotra przed dalszym pójściem za swym Mistrzem (18,15a). Oznacza to, że postawa apostoła, pomimo aspektów negatywnych, nie przekreśliła całkowicie pozytywnych znamion jego osoby: w odróżnieniu od niemal wszystkich pozostałych uczniów, nie był on w stanie wyobrazić sobie, aby miał opuścić Jezusa. Fakt pójścia za Nim objawia wielkie przywiązanie ucznia do Mistrza oraz jest przejawem pewnej jego odwagi $3^{39}$.

Wyparcie się Jezusa. Wpuszczony na dziedziniec domu arcykapłana za przyczyną „innego ucznia” (18,15-16), Piotr nie znalazł jednak w sobie dostatecznych sił, aby zaświadczyć o swej przynależności do Jezusa (18,17.25-27). Nawet jeśli pierwsze dwa pytania skierowane do niego nie były agresywne - w związku z czym nietrudne było udzielenie na nie odpowiedzi, gdyż zaprzeczenie korespondowało z intencją osób pytających i nie wzbudzało żadnych podejrzeń ${ }^{40}$ - należy stwierdzić, że Szymon Piotr prawdziwie i po trzykroć wyparł się swego Mistrza, negując także swą przynależność do kręgu uczniów Jezusa. W przeciwieństwie do Ewangelii synoptycznych

39 Aretius, In Novum, 1007: „Hic primum laudabilis est Petri adhuc diligentia, qui Dominum suum adhuc sequitur et quidem ad certa pericula”; Morris, The Gospel, 665: „It is natural in such a man to want to be near his Lord".

40 Zob. $\mu$ ń w 18,17.25: jest to partykuła negatywna, która - jeśli obecna w zdaniach pytających - oczekuje od interlokutora odpowiedzi przeczacej. Por. Smyth, Greek Grammar, $\$ 2651$; Blass - Debrunner - Rehkopf,

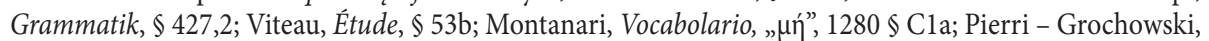
„Una portinaia non ostile”, 234. Pytania te, wypowiedziane przelotnie / pro forma, brzmiałyby po polsku mniej więcej następująco: „(Nie no, chyba) nie jesteś jednym z uczniów tego człowieka? (Byłabym tym zdziwiona / Bylibyśmy tym zdziwieni!)”. 


\section{ZBIGNIEW GROCHOWSKI}

Piotr nie wzbudził od razu żalu po tym, jak dopuścił się zdrady. „Ostatnim głosem narracji” perykopy 18,15-27 stało się pianie koguta, wypełniające ciszę spowodowaną milczeniem ucznia ${ }^{41}$. Choć Szymon Piotr na pewien czas opuścił scenę ewangeliczną (by powrócić dopiero w narracji paschalnej - 20,2), fakt ten niekoniecznie zachwiał w czytelniku nadzieję na to, iż spełnią się profetyczne słowa Jezusa. Pan przepowiedział w Wieczerniku nie tylko zaparcie się Piotra $(13,38)$, lecz także jego przyszłą - tym razem już wierną - wędrówkę śladami Mistrza $(13,36)$, zakończoną męczeńską śmiercią $(21,19.22)$. Dopiero wtedy Szymon stanie się tak naprawdę „Kefasem - Piotrem - Skałą”; pasterzem zdolnym, by paść owce i baranki Jezusa $(21,15-17)$ i nie myśleć już o zachowaniu swego życia, gdy przyjdą prześladowania $(15,20-21)$.

Warto zauważyć kilka zestawień / porównań $(\sigma v \gamma \kappa \rho i ́ \sigma \varepsilon ı \varsigma)^{42}$, które uwypuklają podobieństwa i różnice zachodzące między Piotrem a innymi postaciami w męce Pańskiej u Jana.

Pierwsze porównanie przywołuje Judasza.

1) Zdrada i zaparcie się. Obaj bohaterowie - w sposób nieidentyczny, lecz na zasadzie analogii i podobieństwa - ukazani są jako zjednoczeni ( $\mu \varepsilon \tau^{\prime}$ aủ $\left.\tau \tilde{\omega} v-18,5.18\right)$

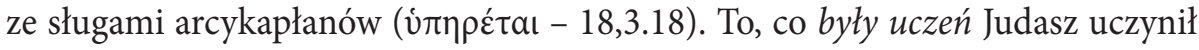
w sposób definitywny, częściowo przypomina także zachowanie się Piotra.

2) Ciemność i zimno. Judasz - ogarnięty przez moce ciemności $(13,27.30)$ - przybył do ogrodu wraz z oddziałem posiłkującym się pochodniami i latarniami $(18,3)$; Piotr grzał się z tymi samymi ludźmi przy ogniu $(18,18.25)$, zważywszy na zimno (również to duchowe), którego właśnie doświadczał.

3) Uzbrojenie. Przeciwnicy Jezusa, przybyli z Judaszem, nieśli w swych rękach broń (ö $\pi \lambda \alpha-18,3$ ), a Piotr użył miecza ( $\mu a ́ \chi \alpha a ı \alpha-18,10-11)$. Wszyscy ewangeliści relacjonują słowa Jezusa, w których potępia On stosowanie przemocy fizycznej przez Judasza i jego ludzi (por. Mk 14,43.48; Mt 26,47.55; Łk 22,47.52) oraz przez Piotra $(18,11)$.

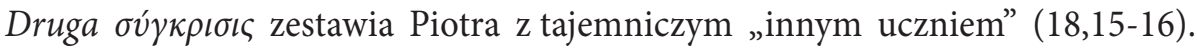
Zauważa się u Kefasa sytuację niefortunną w fakcie „pozostania na zewnątrz, za bramą" $(18,16 a)$, podczas gdy „ów uczeń” - jak gdyby z pozycji wyższości - sprawia, że Piotr może wejść do środka (18,16b). Nie jest to jednak objaw dominacji jednego kompana nad drugim, lecz raczej możliwość skorzystania z faktu bycia „znanym arcykapłanowi” (18,15-16). Obaj uczniowie zasługują na wyróżnienie z racji pójścia za

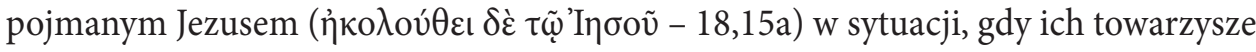
zniknęli ze sceny.

\footnotetext{
41 Por. Grochowski, „Kogut”, 275-276.

42 Por. Lausberg, Retoryka, \$799; Crimella, Marta, Marta!, 34.
} 
Trzecie zestawienie umieszcza obok siebie Piotra i Jezusa ${ }^{43}$.

1) Samoobrona. Piotr używa przemocy $(18,10-11)$, podczas gdy Jezus broni swej godności w sposób dostojny, wyrażając przy tym słowa stanowiące retoryczny dylemat $(18,23)^{44}$.

2) Odwaga i strach. Nie można powiedzieć, że Jezus nie okazał szacunku arcykapłanowi, choć Jego zachowanie charakteryzowało się pełną godnością i odwagą w wypowiadaniu prawdy $(18,19-23)$. Natomiast Piotr, zatrwożony, zachował się bez honoru, negując samego siebie w akcie wypowiadania kłamstwa na temat swej więzi z Jezusem (18,17.25-27).

3) Elementy formalne i strukturalne uwydatniają silny kontrast pomiędzy zachowaniem obu postaci:

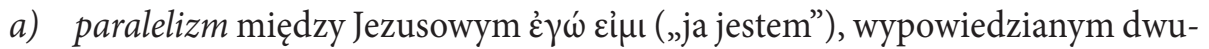
krotnie $(18,5.8)$, a raz przytoczonym przez narratora $(18,6)$, i Piotrowym oủk cỉ $\mu$ í („nie jestem”), również dwukrotnie wyrażonym w mowie niezależnej $(18,17.25)$, a raz zrelacjonowanym w narracyjnym opisie $(18,27)$;

b) figura zwana epanalepsis ${ }^{45}$, objawiająca kunszt czwartego ewangelisty, który po mistrzowsku zaprogramował strukturę perykopy 18,15-27. Polega ona na

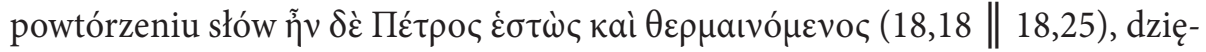
ki czemu - najlepiej ze wszystkich ewangelistów - zdołał on osiągnąć efekt symultaniczności obu zdarzeń: przesłuchania Jezusa przez arcykapłana $(18,19-24)$ i potrójnego zaparcia się Piotra (18,15-18.25-27). Zbieżność czasowa tych epizodów dodatkowo uwypukla kontrast między treścią słów wypowiedzianych przez obu mężów: w momencie, gdy Jezus wskazuje na swoich uczniów jako tych, którzy dadzą świadectwo o nauczaniu Mistrza (18,19-21), jeden z nich, Piotr, właśnie wypiera się swej przynależności do grona uczniów i faktu bycia z Jezusem.

„Okazją" do jakiego objawienia Jezusa staje się Piotr w 18,1-27? Czemu służy tak wyraźnie zarysowany kontrast obecny w zachowaniu obu postaci?

43 Kubiś, „Rhetorical Syncrisis”, 502: , an excellent example is the juxtaposition of Jesus's trial (18:19-24) with that of Peter (18:16-18.25-27)”. Autor wymienia i gruntownie analizuje „Origins”, „Pursuit: Shepherds”, „Deeds or Goods” oraz „Death” jako „The Elements of Johannine Syncrisis between Jesus and Peter” w całej czwartej Ewangelii.

44 Figura ta polega na wytworzeniu takiej sytuacji, w której interlokutor - którekolwiek wybierze rozwiązanie - i tak znajdzie się na przegranej pozycji (por. Lausberg, Retoryka, \$393). Sługa arcykapłana nie jest w stanie udowodnić Jezusowi winy, a zatem - bijąc Go - działa niegodziwie.

45 Czyli „ponowne wzięcie i powtórzenie”; por. Neirynck, „Epanalepsis”, 303, 309; Boismard, „Wiederaufnahme", 235. Narratologia mówi tu o konstrukcji sandwich: A-B-A' (zob. 18,15-18.19-24.25-27); por. Lincoln, John, 449; Matera, „Jesus before Annas”, 50; Heil, Blood and Water, 2; Marguerat - Bourquin, Racconti biblici, 59-60. 


\section{ZBIGNIEW GROCHOWSKI}

Pierwsza perykopa $(18,1-14)$ dotyka tematu misji Jezusa. Uczeń, stosując przemoc, chciał ją obronić przed ingerencją nieprzyjaciół, podczas gdy Mistrz objawił, że na jej realizację składa się także konieczność podjęcia męki. Pokazał, że „pełnienie woli” Ojca i „wykonanie Jego dzieła” $(4,34 ; 6,38 ; 17,4)$ związane jest również z rosnącym napięciem i kontrowersjami z tymi, którzy chcieli Go zabić $(5,16.18 ; 7,1.19 .25$; $8,40.59 ; 10,31.39 ; 11,53)$. Obrazem misji Jezusa stał się więc „kielich”, który Mistrz przeciwstawił „mieczowi” Piotra. Figura retoryczna interrogatio / غ̇ $\rho \omega ́ \tau \tau \mu \alpha$, czyli pytanie postawione nie po to, żeby się czegoś dowiedzieć, lecz aby z jeszcze większą siłą stwierdzić pewien niezaprzeczalny fakt ${ }^{46}$ - „Kielich, który podał mi Ojciec, czyż nie mam go pić?” $(18,11)$ - w sposób zdecydowany określiła przyczynę, dla której Jezus odrzucił osobistą obronę za pomocą użycia siły. Uczeń stał się więc okazją, dzięki której Mistrz mógł powiedzieć, że Jego misja osiągnie zwycięstwo nie przy użyciu miecza, lecz dzięki wychyleniu kielicha goryczy; nie przez zastosowanie przemocy, lecz dzięki wstąpieniu na krzyż.

W drugiej perykopie $(18,15-27)$ zauważa się ogromny kontrast obecny w odpowiedziach Jezusa i Piotra na postawione im pytania. Uczeń przestraszył się odźwiernej i strażników oraz wyparł Jezusa, natomiast Mistrz w czasie żydowskiego procesu dał odważne świadectwo prawdzie. W tym przypadku objawienie Jezusa nie było jednak "sprowokowane" bezpośrednio jakimś słowem lub czynem Piotra (jak to miało miejsce w poprzedniej perykopie), ale stało się widoczne dzięki zestawieniu (бúүкрıбıৎ) dwóch postaw, które - choć mające miejsce w tym samym czasie i podobnej przestrzeni - przybrały jednak zgoła inną postać. Ze słowami Piotra, negującymi fakt bycia uczniem Jezusa $(18,17.25)$ oraz przebywania z Nim w Ogrójcu $(18,26-27)$, kontrastowały odpowiedzi Jezusa udzielone na pytania arcykapłana $(18,20-21)$ i jego sługi $(18,23)$ : one potwierdziły Jego niewinność, odwage w świadczeniu o prawdzie oraz ufność złożoną we własnych „słuchaczach”, uczniach. Kompozycja perykopy, oparta na schemacie ABA', przyczynia się do tego, że objawienie - wyrażone za pomocą własnych słów i czynów Jezusa $(18,19-24)$ - dzięki kontrastowi ze słowami i postawą Piotra, stało się jeszcze bardziej widoczne i zrozumiałe ${ }^{47}$.

\section{Inny uczeń - umiłowany uczeń}

Jest postacią anonimową, a ustalenie jego tożsamości stanowi crux interpretum, jest bowiem niemałym wyzwaniem dla egzegetów.

46 Lausberg, Retoryka, $\$ 768$ : „interrogamus etiam quod negari non possit”.

47 Biorąc natomiast pod uwagę obie perykopy pierwszej części męki Pańskiej jako całość (18,1-27), widzimy jeszcze jeden znamienny kontrast: „Jesus confirms (...) his divine status, while Peter denies his status as a disciple” (Kubiś, „Rhetorical Syncrisis”, 518). 


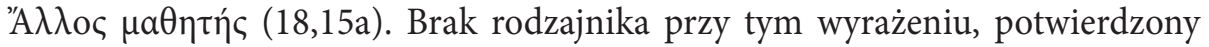
gruntowną krytyką tekstualną ${ }^{48}$, prowadzi do wniosku, że postać ta nie jest tożsama z umiłowanym uczniem, znanym czytelnikowi czwartej Ewangelii już od wersetu $13,23^{49}$. Z drugiej strony, zwłaszcza w świetle wersetu 20,2, gdzie jest mowa o „innym uczniu, którego Jezus kochał” ( oraz przy uwzględnieniu 20,3.4.8, gdzie ów „inny uczeń" przedstawiony jest konse-

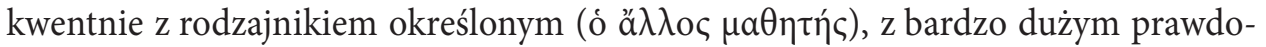
podobieństwem można mówić o „połączeniu” przez ewangelistę w jednej i tej samej osobie obu postaci ${ }^{50}$. Oznaczałoby to, że uczeń, który umożliwia Piotrowi wejście na dziedziniec domu arcykapłana (18,15-16), to ten "umiłowany przez Jezusa"51. W jaki jednak sposób wyjaśnić zjawisko, które stoi w sprzeczności z zasadami gramatyki? Próbą rozwiązania powyższego dylematu jest następująca hipoteza: ewangelista opuścit rodzajnik o w 18,15a intencjonalnie, czyniąc to ze względu na czytelnika perykopy 18,15-27, rozumianego jako the first-time reader ${ }^{52}$. Celem takiego zabiegu byłoby uniknięcie efektu oderwania uwagi czytelnika od bohaterów pierwszorzędnych tego tekstu (Jezusa i Piotra). Jest bowiem niemal pewne, że skupienie się czytelnika na tych protagonistach mogłoby ulec rozproszeniu w momencie zapoznania się z informacją zgoła „sensacyjną” (żeby nie powiedzieć: gorszącą), a niewątpliwie wzbudzającą zdziwienie i rodzącą pytanie: w jaki sposób „uczeń umiłowany przez Jezusa” może być jednocześnie kimś „znanym arcykapłanowi” (18,15-16)? Zwłaszcza że ta znajomość - podkreślona przez ewangelistę dwukrotnym przytoczeniem

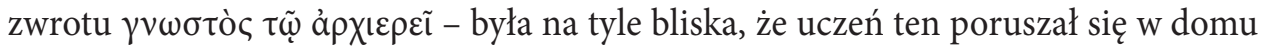
arcykapłana bardzo swobodnie, mając między innymi duży posłuch u odźwiernej pilnującej bezpieczeństwa tego miejsca. Czy czytelnik nie przeżyłby lekkiego „szoku” w związku z faktem, że jest to „umiłowany uczeń" - w sytuacji, gdy jego bliski znajomy, arcykapłan, jednocześnie nastaje na życie Mistrza? ${ }^{33}$

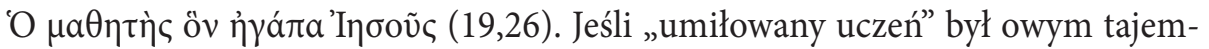
niczym „innym uczniem” (18,15-16), oznacza to, że postać ta - aż do 19,25-27 - była uczniem pozostającym $w$ ukryciu. Śmiałość, z jaką poruszał się on w pałacu Annasza

48 Por. Grochowski, Discepolo, 147-149.

49 Janusz Kręcidło („Tożsamość Umiłowanego Ucznia”, 45-58) nie wspomina rozdziału 18 Ewangelii Janowej w swoich analizach.

50 Por. Neirynck, „Other Disciple”, 113-141.

51 Por. Sikora, „Uczeń”, 88-89, 94-96. Według Ryszarda A. Sikory („Uczeń”, 88-92) postać ta jest tożsama także z anonimowym uczniem Jana Chrzciciela (1,35-40), czego nie można wykluczyć. Szerzej na te tematy: Sikora, Zobaczyt, 9, 13-35, 59-74.

52 Według ekspertów narratologii taki czytelnik jest osobą, która - w wyobrażeniu autora - czyta tekst po raz pierwszy w życiu i czyni to ściśle przestrzegając zasady polegającej na zgłębianiu treści książki z zachowaniem kolejności zdarzeń opowiedzianych w narracji. W żaden sposób nie zna więc on rozwiązań, które dopiero nastapią. Por. Powell, Narrative Criticism, 19; Crimella, Marta, Marta!, 44.

53 Dla Sikory (Zobaczył, 66) „,[] najomość ta mogła mieć dość luźny charakter (...) u jej podstaw mogła stać na przykład przynależność do stanu kapłańskiego czy posługa, jaką wobec pałacu mógł on pełnić z racji swego zawodu". 


\section{ZBIGNIEW GROCHOWSKI}

(lub Kajfasza) $(18,15-16)$ prowadzi do zinterpretowania terminu „znany” ( $\gamma v \omega \sigma \tau o ́ \varsigma)$ w sensie ścisłym: znany, ale nie jako uczeń Jezusa. Arcykapłani wraz ze swym otoczeniem, widząc go obecnego przed krzyżem (19,26-27.35), byli niewątpliwie zdziwieni, że przynależy on do kręgu uczniów Jezusa. W konsekwencji zakres świadectwa danego przez umiłowanego ucznia rozszerzył się: reprezentował on już nie tylko uczniów, którzy dawno uciekli z ogrodu, ale jego tożsamość wyszła na jaw także ze względu na osoby będące blisko arcykapłanów. Czy jego obecność przed krzyżem nie wpłynęła pozytywnie m.in. na Józefa z Arymatei i Nikodema? Warto na koniec dodać, że umiłowany uczeń, ukrywający swą przynależność do Jezusa (a czyniący to - jak się zdaje - nie ze strachu, lecz z roztropności), mógł stać się świadkiem zdarzeń dziejących się w domu arcykapłana ${ }^{54}$.

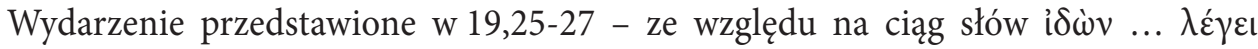
... ‘ $\delta \varepsilon$ („widząc ... mówi / rzekł ... oto!”) - realizuje „schemat objawienia”" ${ }^{\text {. }}$. Umiłowany uczeń, stojący na Kalwarii wraz z Matką Jezusa, stworzył Ukrzyżowanemu okazję do objawienia kolejnego stopnia Jego miłości. Po tym, jak stał się on uczniem „umiłowanym”, spoczywającym na piersi Pana (por. 13,23), został teraz zaproszony przez Mistrza, by stać się wręcz Jego „bratem”"56. Dar Jezusa polegający na powierzeniu uczniowi swojej Matki kreuje nową relację charakteryzującą się wzajemnością.

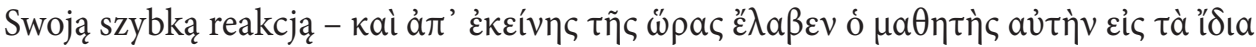
$(19,27 d)$ - uczeń, jeszcze w tej samej „godzinie”, przyjął objawienie Mistrza i uczynił możliwą realizację nowej relacji rodzinnej, której on sam także stał się uczestnikiem. Można powiedzieć, że w pewnym sensie Mistrz potrzebował swoich uczniów, aby Jego objawienie zostało wypowiedziane i zrealizowane. Nawet jeśli słowa Jezusa już same w sobie mają performatywną virtus - siłą samego tylko wyrażenia formuły: „oto syn Twój” I „oto Matka twoja”, oboje zostają ściśle złączeni relacją Matki i syna - upoważnioną jest konstatacja, że pragnienie Jezusa co do utworzenia nowej rodziny - aby mogło się zrealizować - wymagało pozytywnej odpowiedzi ze strony ucznia i Matki. Rzecz ofiarowana urzeczywistnia zamiar dawcy oraz staje się w pełni „darem” właściwie dopiero wtedy, gdy jest przyjęta. Jest zatem istotne, że umiłowany uczeń nie uciekł, lecz był tam obecny. Dzięki temu mógł usłyszeć słowa umierającego Mistrza i natychmiast je zrealizować. Ponadto reprezentując wiarę wszystkich uczniów, zarówno rozproszonych, jak i tych przyszłych, dał początek Bożej rodzinie (1,11-12). Objawi się ona już w narracji paschalnej, w której uczniowie zajmą

\footnotetext{
54 Szczepański, Bóg - Człowiek, 366: „ów «drugi uczeń» (św. Jan?) pośpieszył za Panem Jezusem do sali, w mieszkaniu Annasza i był świadkiem przesłuchania, które opowiada (Jan 18,19-23)”.

55 Por. de Goedt, „Un Schème de Révélation”, 142-150; Serra, Contributi, 422-423; Witczyk, „Historia”, 266. Inne testy opierające się na tym „schemacie”, to: $1 \mathrm{Sm}$ 9,17; J 1,29-34.35-39.47-51.

56 Por. Kręcidło, „Tożsamość Umiłowanego Ucznia”, 50-52; Sikora, „Uczeń”, 96.
} 
miejsce krewnych Jezusa, stając się Jego braćmi (20,17-18) oraz braćmi między sobą $(21,23)$. Ten uczeń, który przed krzyżem Jezusa stał się świadkiem zbawczej śmierci Mistrza (19,35a), mógł w konsekwencji dać wszystkim wiarygodne świadectwo $(19,35 b ; 21,24)$, aby wszyscy wierzyli w Jezusa Mesjasza $(20,31)$ i - stając się członkami nowej Bożej rodziny $(1,12)$ - mieli życie wieczne (20,31). Innymi słowy, dzięki świadectwu umiłowanego ucznia $(19,35)$ objawienie Jezusa związane z najwyższym stopniem Jego miłości może być znane wszystkim ludziom i w konsekwencji przez nich przyjęte jako dar braterstwa $z$ Jezusem ${ }^{57}$.

\section{Matka Jezusa i kobiety}

Pewne treści związane z umiłowanym uczniem dotyczą także kobiet obecnych na Golgocie (19,25). Również ich postawa zasługuje na uznanie. Podczas gdy uczniowie - z wyjątkiem tego „umiłowanego" - już dawno zniknęli (18,12-14), a żołnierze rzymscy dzielili właśnie między siebie szaty Jezusa (19,23-24), kobiety wiernie i od-

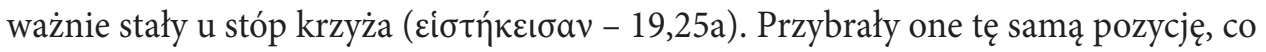

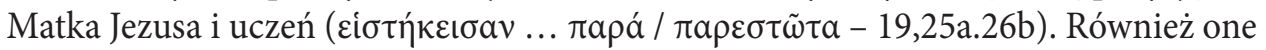
poszły za Panem z Galilei do Jerozolimy, aż na Kalwarię. Zasłużyły zatem na miano

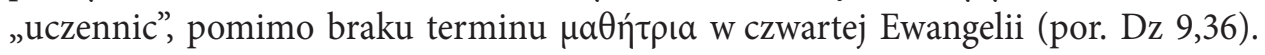
Warto zauważyć, że wraz z Matką i uczniem utworzyły one grupę pięcioosobową ${ }^{58}$, czyli niezbędne minimum - według tradycji rabinicznej - by autorytet, za którym poszli/-ły, mógł zasługiwać na miano „mistrza”59. Co więcej, inspirują one do przy-

57 Por. Gryglewicz - Mędala - Chmiel, „Tradycja św. Jana”, 475: „Z krzyża [Jezus] objawia - w osobie umiłowanego ucznia - wszystkich ludzi jako dzieci Boże, a Maryję jako ich matkę".

58 Jest to (jedynie) hipoteza, choć posiadająca swoje silne argumenty. Problem tkwi w znalezieniu odpowiedzi na pytanie: czy „siostra Matki Jego” oraz „Maria Kleofasowa” to jedna i ta sama osoba, czy też - jak zakłada niniejsze studium - dwie odrębne kobiety? Zauważa się brak spójnika kaí między tymi wyrażeniami, obecnego natomiast po zwrocie „Matka Jego” i przed „Maria Magdalena”. Może więc są to dwie pary kobiet, których prezentacja - dzięki zastosowaniu asyndetonu - osiągnęła piękny efekt paralelizmu: dwie pierwsze kobiety są anonimowe, a dwie kolejne to znane z imienia Marie? Obecne w Nowym Testamencie listy apostołów nie dają rozstrzygającego rozwiązania. Są oni bowiem wymieniani bądź to parami (por. Mt 10,2-4), bądź to pojedynczo (por. Mk 3,16-19; Łk 6,14-16), lub też w systemie mieszanym (Dz 1,13). Aczkolwiek warto zauważyć, że listy te - w miejscach, w których występuje appositum, czyli epitet, przymiotnik, dookreślenie danej postaci - za każdym razem w pierwszej kolejności podają imię apostoła (dopiero potem jego charakterystykę). Również wszystkie wystąpienia rzeczownika „siostra” (åd $\delta \lambda \varphi \eta ́)$ w Septuagincie i w Nowym Testamencie przechylają szalę na korzyść postrzegania w „siostrze Matki Jego” kobiety innej niż „Maria Kleofasowa”. Częściej bowiem (12 razy) występuje schemat „imię siostra" (por. Rdz 46,17; Wj 15,20; 2 Sm 13,5.6; 2 Krl 11,2; 1 Krn 3,19; 7,30; 2 Krn 22,11; Ez 16,48.56; 23,4; Flm 1,2), a rzadziej (6 razy) schemat „siostra - imię” (por. 1 Krl 11,20; 1 Krn 7,18; Ez 16,55; 23,11; Łk 10,39; ; 11,39).

59 Por. Bacher, „Christianity in Talmud”, 180; Safrai, „Jesus”, 99-101; Bauckham, „Nicodemus”, 36; Flusser, „Isaiah”, 320 i przyp. 32-34; Manns, Ecce Homo, 62: „Yehoshuä aveva allora cinque discepoli, pertanto 


\section{ZBIGNIEW GROCHOWSKI}

wołania scen opowiedzianych na początku Ewangelii, gdzie Jezus - rozpoczynając swą publiczną działalność - zgromadził wokół siebie pierwszych pięciu uczniów. Oba teksty (1,35-51 i 19,25-27) tworzą tym samym klamrę kompozycyjną (inkluzję) i potwierdzają, że Jezus przez cały czas - od pierwszych chwil pełnionej przez siebie misji, aż po ostatnie tchnienie - jawi się jako prawdziwy i autentyczny Mistrz z Nazaretu.

Jak widać, do wędrówki śladami Jezusa powołani są nie tylko mężczyźni, lecz także kobiety. Ich obecność przed krzyżem dała im możliwość usłyszenia ostatnich słów Jezusa, a zatem bycia świadkami - więcej - uczestniczkami Jego testamentu, który objawia i konstytuuje nowy rodzaj pokrewieństwa. Choć wypowiedzi Mistrza skierowane były bezpośrednio do Matki i ucznia, również kobiety - jako uczennice i siostry Jezusa - znalazły swoje miejsce w nowoutworzonej Bożej rodzinie.

Niemniej jedyną w swoim rodzaju kobietą i uczennicą była tam Matka Jezusa.

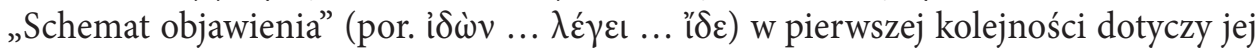

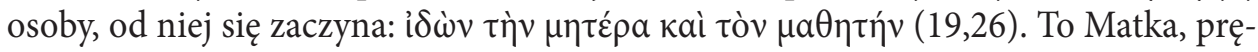
dzej niż uczeń, stała się locus objawienia Mistrza: „Niewiasto, oto syn Twój!”. Oczy i słowa Jezusa skierowały jej spojrzenie nie tyle na siebie, ile ku uczniowi. To, co na pierwszy rzut oka mogłoby wydawać się „zastąpieniem” Syna przez ucznia, było w rzeczywistości rozszerzeniem zakresu macierzyństwa Maryi. Gdy Jezus objawiał kolejny stopień miłości do ucznia, czyniąc go swoim bratem, zaprosił także Matkę do rozciągnięcia Jej miłości na kolejnego syna, a w nim na wszystkich uczniów i uczennice. W godzinie swej próby Jezus zwiększył skalę miłości i zaprosił do uczynienia tego samego. Co się tyczy adresatów objawienia Jezusa, napisane jest, że w tejże samej chwili uczeń wykonał zadanie wynikające z treści usłyszanych słów: „I od tej godziny uczeń wziął Ją do siebie" $(19,27)$. Jest jednak w tych słowach zawarta dyskretna myśl, że również Matka bez wahania przyjęła objawienie Syna, wyrażając zgodę na to, by przylgnąć do nowego syna. Matka i uczeń - swą wspólną (choć podjętą indywidualnie) decyzją - stworzyli słowom Mistrza możliwość, by Jego plan miłości stał się rzeczywistością.

\section{Józef z Arymatei i Nikodem}

Józef z Arymatei, znany z Ewangelii synoptycznych jako członek Sanhedrynu, przedstawiony jest w czwartej Ewangelii zarówno pozytywnie - jako „uczeń Jezusa”, jak

meritava il titolo di rabbì, quantunque non avesse frequentato le yeshivòt dei farisei”; idem, „Encore une fois”, 34. Szerzej na ten temat: Grochowski, „Cinque discepoli”, 11-26. 
i negatywnie - z adnotacją: „ale w ukryciu z obawy przed Żydami” (19,38). Kontekst narracyjny wyjaśnia ten szczegół ${ }^{60}$, a zwłaszcza komentarz na temat przywódców ludu, że mianowicie wielu z nich uwierzyło w Jezusa, „ale z obawy przed faryzeuszami nie przyznawali się, aby ich nie wyłączono z Synagogi. Bardziej bowiem umiłowali chwałę ludzką aniżeli chwałę Bożą" (12,42b-43). Józef z Arymatei znalazł jednak w końcu odwagę, by zaświadczyć publicznie o swym przylgnięciu do Jezusa, wzgardziwszy czysto ziemskim prestiżem i poważaniem wśród ludzi.

Nikodem jest z kolei postacią obecną tylko w czwartej Ewangelii. Podobnie jak Józef z Arymatei, jest „faryzeuszem, dostojnikiem żydowskim” (3,1). Brakuje jednak określenia go mianem „uczeń Jezusa”. Narracyjna technika telling \& showing ${ }^{61}$ po-

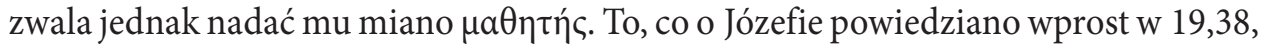
znajduje swoje odzwierciedlenie w narracji opowiadającej o słowach i czynach Nikodema, ukazującej trzystopniowy proces jego wzrostu w wierze ${ }^{62}$ : od nocnej, a więc jeszcze w aurze lęku i niezrozumienia, rozmowy z Jezusem $(3,1-21)^{63}$, poprzez już dość odważną interwencję u arcykapłanów i faryzeuszów w sprawie Mistrza z Galilei $(7,45-53)$ aż po przygotowanie pogrzebu Jezusa wspólnie z Józefem z Arymatei (19,39-42). Ostatni czyn przywołuje między innymi gest Onqelosa, który uczcił rabbiego Gamaliela Starszego, spalając na jego cześć około 35-40 kg wonności podczas jego pogrzebu (por. bAZ 11a; bSem 8,6) ${ }^{64}$. Nikodemowe 100 funtów mieszaniny mirry i aloesu (ok. 32,5 kg) oraz pozostałe gesty mogą być wyrazem jego coming out jako ucznia Jezusa ${ }^{65}$.

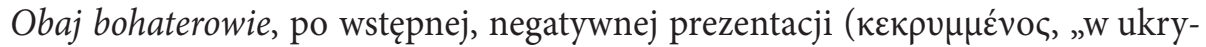
ciu” / vuktós, „nocą” - 19,38-39) ${ }^{66}$, ukazani są ostatecznie jako odważni świadkowie Jezusa, wyprawiający swemu Mistrzowi pochówek godny króla. Pociągnięci wizją Ukrzyżowanego $(3,14-17 ; 8,28 ; 12,32-33)$ i prawdopodobnie zachęceni postawą kobiet oraz zwłaszcza umiłowanego ucznia, pokonali w sobie lęk i nie martwiąc się już o swą pozycję w Sanhedrynie (a mogli być pewni wykluczenia i dalszych szykan ${ }^{67}$ ), uczcili ciało zmarłego Jezusa. Przenieśli także na później celebrację Paschy z racji

60 Por. ảंoбvvá $\gamma \omega \gamma \circ \varsigma-9,22 ; 12,42 ; 16,2$.

61 Resseguie, Strange Gospel, 126-127: „In showing, which is also called the dramatic method or indirect presentation, the author simply presents the characters talking and acting and leaves the reader to infer the motives and dispositions that lie behind what they say and do (...) In telling, which is also called direct presentation, the narrator intervenes to comment directly on a character - singling out a trait for us to notice or making an evaluation of a character and his or her motives and disposition". Por. Ska, Our Fathers, 53-54; Marguerat - Bourquin, Racconti biblici, 75-77.

62 Por. Maranesi, La verità di Nicodemo, 6-8.

63 Por. Whitenton, „The Dissembler”, 141-158; Filtvedt, „Nicodemus's Question”, 110-140.

64 Por. Zlotnick - Kutscher, The Tractate "Mourning", 20.

65 Por. Whitenton, Configuring Nicodemus, 115.

66 W przypadku Nikodema tò $\pi \rho \tilde{\omega} \tau o v$ („po raz pierwszy” - 19,39) przywołuje sytuację (za)przeszłą z 3,2, która już 7,50-52 została „pokonana / przezwyciężona”.

67 Por. Brant, John, 255. 


\section{ZBIGNIEW GROCHOWSKI}

nabytej przy tej okazji nieczystości rytualnej ${ }^{68}$ : „dla nich liczy[ła] się [wtedy już tylko] Pascha Jezusa"69. Wydaje się, że nie powinno być wątpliwości, iż są oni uczniami Jezusa zasługującymi na uznanie ${ }^{70}$.

Perykopa 19,31-42, której część stanowi fragment 19,38-42 związany z Józefem i Nikodemem, opisuje wydarzenia mające miejsce po śmierci Jezusa, a przed Jego zmartwychwstaniem, czyli jedyny moment, kiedy Jezus nic nie mówi ani cokolwiek czyni: jest martwy. Nie oznacza to jednak, że przestał się objawiać. Dzięki aktywności tych dwóch uczniów, jak gdyby w lustrze / refleksie, Jezus wciąż komunikuje światu swoje objawienie, zwłaszcza dotyczące Jego tożsamości. Ilość i jakość wonności, drogocenne płótna oraz fakt, że Jezusa pochowano w ogrodzie, przywołują na myśl pogrzeby królów, takich jak Dawid, Asa, Manasses, Amon i Herod Wielki ${ }^{71}$, a także prawdopodobnie jeszcze kilkunastu innych ${ }^{72}$. Dokonuje się więc tutaj objawienie Jezusa jako mesjańskiego Króla ${ }^{73}$. Analogia do gestu Onq losa wskazuje na Jezusa jako

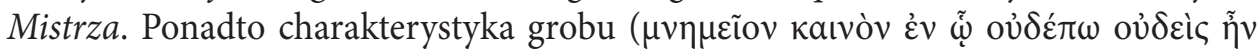
$\tau \varepsilon \theta \varepsilon \iota \mu \varepsilon ́ v o \varsigma$ - 19,41) może sugerować podkreślenie świętości Jezusa. A jako że w J 7, gdy Nikodem wziął w obronę Galilejczyka, toczyły się kontrowersje na temat Jego ewentualnej misji (nie tylko mesjańskiej, ale także i) prorockiej (7,25-27.40-44), można stwierdzić, że faryzeusz całą swą działalnością uwypuklił również ten aspekt Jezusowej tożsamości: Prorok posłany przez Boga.

Jest jeszcze jedna sprawa godna podkreślenia. Widok Ukrzyżowanego, a więc człowieka (pozornie) przegranego, zamiast nakłonić Józefa i Nikodema do potwierdzenia wobec samych siebie słuszności przybrania postawy bycia uczniem $w$ ukryciu i doprowadzić do definitywnego zerwania jakikolwiek związków z Jezusem, wręcz przeciwnie - zachęcił ich do publicznego wyznania wiary i dołączenia do grona Jego uczniów ${ }^{74}$. W ten sposób, paradoksalnie, $w$ uniżeniu krzyża objawiła się chwała Ukrzyżowanego. To ona przekonała obu dygnitarzy, aby wyjść z ukrycia. Jednocześnie, dzięki ich świadectwu, chwała Krzyża została objawiona światu, na potwierw odniesieniu do zdarzeń opowiedzianych w J 7, ale także nawet w J 19; por. Culpepper, „Nicodemus”,
258-259; Bennema, „Nicodemus”, 155-158 i dziesiątki innych studiów. Próbą odrzucenia ich argumentacji jest artykuł: Grochowski, „Nicodemus”, 637-676.

71 Por. 2 Krl 21,18.26; 2 Krn 16,14; Ne 3,16 (LXX); Flawiusz, Bellum Iudaicum 1,670-673 i Antiquitates Iudaicae 17,196-199.

72 Por. Grochowski, „Nicodemus”, 660-661.

73 Por. Dschulnigg, Jesus begegnen, 119; Draper, „What Did Isaiah See?”, 69; Dietzfelbinger, Johannes, 315; Hendriksen, Exposition, 445.

74

Zob. Lb 9,10-11. Por. Mateos - Barreto, Juan, 835; Burge, John, 535; von Wahlde, The Gospel, 830-831.

Por. Vignolo, Personaggi, 118; Bruner, John, 1135.

Nie brakuje niestety egzegetów, którzy negatywnie oceniają zachowanie Nikodema, a czynią to nie tylko Por. Koester, „Theological Complexity”, 180. 
dzenie słów Jezusa o mającym nastąpić Jego „wywyższeniu” $(3,14 ; 8,28 ; 12,32.34)^{75}$. Bez trudu zauważa się, że pierwsza $\mathrm{z}$ tych wypowiedzi została sformułowana wobec Nikodema $(3,14)$.

\section{Zakończenie}

Już dawno do potocznego języka weszły sformułowania typu „to jest jego godzina próby”, „przyszła na nią jej godzina” itp. Mają one swe źródło w Ewangeliach, gdzie najczęściej kojarzone są z osobą Jezusa i Jego zbawczą męką oraz śmiercią. Zauważa się jednak, że w czwartej Ewangelii sam Chrystus zapowiada nie tylko swoją "godzinę", lecz także trudne doświadczenia mające przyjść na Jego uczniów. Czekają ich przyszłe prześladowania (16,2.4.21), ale pierwszym momentem stawienia czoła poważnej próbie będzie już „za chwilę” pojmanie ich Mistrza w Ogrójcu. Tu najwyraźniej widać, jak godzina Jezusa zbiega się z godziną uczniów (16,32).

Niniejsze studium zaprezentowało sześć typów postaw przyjętych przez poszczególnych uczniów w J 18-19. Zauważa się, że w pierwszej części męki Pańskiej (18,1-27) ich świadectwo przedstawia się raczej negatywnie: zniknięcie większości uczniów ze sceny już podczas aresztowania Jezusa, zdrada Judasza, zaparcie się Piotra. Natomiast w drugiej $(19,16-42)$ pozostałe osoby z kręgu Chrystusa przybrały już postawę pozytywną: trwanie umiłowanego ucznia, Matki Jezusa i kobiet przy Ukrzyżowanym oraz wyjście z ukrycia dwóch uczniów będących członkami Sanhedrynu Józefa z Arymatei i Nikodema.

Celem niniejszego artykułu było jednak nie tylko pogrupowanie uczniów Jezusa według kategorii ich zachowań, lecz także zastanowienie się, jaką to funkcję służebną mogą pełnić ich postawy względem Jezusowego objawienia. Okazuje się bowiem, że Chrystus przemawia nie tylko za pośrednictwem własnych słów i czynów, lecz dzięki interakcjom $z$ innymi postaciami potwierdza i wzmacnia swoje objawienie lub wręcz wyraża je tylko poprzez działanie swych uczniów (przypadek Nikodema i Józefa z Arymatei).

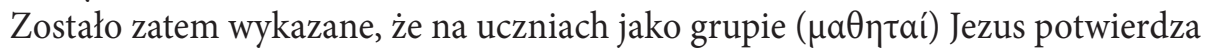
swą suwerenność (jest Panem sytuacji), wykazuje autorytet Mistrza, objawia się jako Prorok potężny w słowie, wyraża miłość Dobrego Pasterza, który daje życie za swe owce / uczniów.

Na osobie Piotra Jezus objawia istotę swej misji zbawczej i gotowość przyjęcia kielicha męki z rąk Ojca. Dając Szymonowi reprymendę (na uderzenie mieczem) pokazał, że swej godności należy bronić w sposób rozważny, z honorem, nie czyniąc agresorowi żadnej krzywdy. W domu arcykapłana wybrzmiewa natomiast prawda -

75 Kubiś, „Zechariah”, 170: „The Johannine (...) Jesus' crucifixion is the hour of his glorification”. 


\section{ZBIGNIEW GROCHOWSKI}

wzmocniona (na zasadzie kontrastu) antyprzykładem Piotra - że Jezus odważnie głosi prawdę, zachowuje się godnie i pokłada nadzieję w swych uczniach (podczas gdy Piotr zaprzeczył wszystkim tym wartościom i - jako uczeń - zawiódł Mistrza).

Judasz - eks-uczeń - swym upadkiem na ziemię wraz z uzbrojonym oddziałem $(18,6)$ potwierdził prawdę o bóstwie Chrystusa, wyrażoną słowami „Ja jestem” ( $\dot{\varepsilon} \gamma \omega ́$ Eìu / 'ănî hû').

Umiłowany uczeń wraz z Matką Jezusa, wyrażając zgodę na przyjęcie „testamentu z krzyża" i natychmiast realizując jego przesłanie - już w tej "godzinie” (å $\pi^{\prime}$

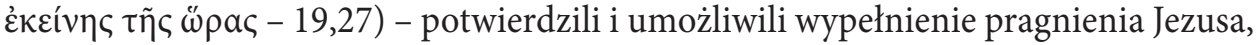
by objawić najwyższy stopień swej miłości względem uczniów: zaproszenie ich do Bożej rodziny i uczynienie ich swymi braćmi i siostrami.

Niezmiennie doskonały obraz umiłowanego ucznia oraz kobiet wzbogacony jest na koniec świadectwem Józefa z Arymatei i Nikodema, dotychczas ukrytych uczniów Jezusa. W godzinie wywyższenia Chrystusa na krzyżu zostali oni „wyciągnięci” (por. 12,32) z ciemności lęku i niewiary. Wyprawiając Jezusowi pełen przepychu pogrzeb, potwierdzili kilka ważnych aspektów Jego tożsamości. W przypadku gestu tych dwóch mężów ma miejsce wyjątkowa sytuacja: to jest jedyny moment w Ewangelii, kiedy Jezus nic nie mówi ani czyni - On nie żyje, umarł na krzyżu. Nie przestaje jednak objawiać się światu, czyniąc to jakby w refleksie, na osobach tych dwóch pozyskanych właśnie uczniów. Józef z Arymatei i Nikodem stają się zatem „okazją", locus theologicus, w której Jezus objawia się jako Mesjasz, Król, Święty, Prorok, a także Mistrz godzien gestów miłości ze strony swoich uczniów.

Niniejsze studium dotyka zatem kilku zagadnień natury teologicznej, bliskiej dogmatyce i teologii fundamentalnej. Niesie ono jednak również przesłanie o charakterze praktycznym, dotyczącym chrześcijańskiej moralności. Bardzo skrótowa prezentacja postaw uczniów ma na celu zachęcić czytelnika do naśladowania pozytywnych ich aspektów oraz unikania tego, co sprzeciwia się wytycznym Mistrza. Przestroga przed antyprzykładami nie gasi jednak pewności co do tego, że Pan Bóg, nawet przy najbardziej niefortunnym zachowaniu uczniów, ostatecznie przeprowadzi swój plan zbawienia.

Bożemu osądowi należy zostawić decyzję o wiecznym losie Judasza. Natomiast Józef z Arymatei, a zwłaszcza Nikodem, stają się dla czytelnika prawdopodobnie najlepszym przykładem do naśladowania. Doświadczenie życiowe większości ludzi uczy bowiem, że człowiek potrzebuje nawrócenia, a trzyetapowy proces wzrostu Nikodema w wierze jest tego pięknym przykładem. Uczeń stopniowo wychodzi z ciemności lęku i niewiary, by w końcu dać publiczne świadectwo o swym przylgnięciu do Jezusa.

Niech „godzina próby uczniów Chrystusa”, oznajmiona przez Mistrza w 16,32, a opowiedziana przez ewangelistę w rozdziałach 18-19, inspiruje czytelników do wierności swemu Panu oraz objawiania światu prawdy o tym, kim jest Jezus. 


\section{Bibliografia}

Aretius, B., In Novum Testamentum Domini nostri Iesu Christi Commentarii Doctissimi Benedicti Aretii Bernensis Theologi praestantissimi, facili perspicuaque methodo conscripti (Genevae: Chouët 1618).

Bacher, W., „R. Travers Herford's «Christianity in Talmud and Midrash»”, Jewish Quarterly Review 17 (1904) 171-183.

Bauckham, R., „Nicodemus and the Gurion Family”, Journal of Theological Studies 47 (1996) 1-37.

Beck, D.R., The Discipleship Paradigm. Readers and Anonymous Characters in the Fourth Gospel (Biblical Interpretation Series 27; Leiden - New York - Köln: Brill 1997).

Bennema, C., „Nicodemus: In the Twilight Zone”, Encountering Jesus. Character Studies in the Gospel of John, wyd. 2 (red. C. Bennema) (Minneapolis, MN: Fortress 2014) 147-160.

Beutler, J., „Die Stunde Jesu im Johannesevangelium”, Studien zu den johanneischen Schriften (red. J. Beutler) (Stuttgarter biblische Aufsatzbände 25; Stuttgart: Katholisches Bibelwerk 1998) 317-322.

Blass, F. - Debrunner, A. - Rehkopf, F., Grammatik des neutestamentlichen Griechisch, wyd. 18 (Göttingen: Vandenhoeck \& Ruprecht 2001).

Boismard, M.-É., „Un procédé rédactionnel dans le quatrième évangile: la Wiederaufnahme”, L'Évangile de Jean. Sources, rédaction, théologie (red. M. de Jonge) (Bibliotheca Ephemeridum Theologicarum Lovaniensium 44; Gembloux - Leuven: Duculot - Leuven University Press 1977) 235-241.

Borrel, A., „Els Dotze després de Jesus”, Revista Catalana de Teologia 29 (2004) 289-304.

Brant, J.-A.A., John (Grand Rapids, MI: Baker Academic 2011).

Brown, R.E., „ "Other Sheep Not of This Fold»: The Johannine Perspective on Christian Diversity in the Late First Century", Journal of Biblical Literature 97 (1978) 5-22.

Brown, R.E., The Community of the Beloved Disciple (New York - Mahwah, NJ: Paulist Press 1979).

Bruner, F.D., The Gospel of John. Commentary (Grand Rapids, MI - Cambridge: Eerdmans 2012).

Burge, G.M., John. From Biblical Text ... to Contemporary Life (The NIV Application Commentary 4; Grand Rapids, MI: Zondervan 2000).

Buscemi, A.M., L'uso delle preposizioni nella Lettera ai Galati (Studium Biblicum Franciscanum Analecta 17; Jerusalem: Franciscan Printing Press 1987).

Carroll, J.T. - Green, J.B., „The Death of Jesus in the Gospel According to John”, The Death of Jesus in Early Christianity (red. J.T. Carroll et al.) (Peabody, MA: Hendrickson 1995) 82-109.

Chennattu, R.M., Johannine Discipleship as a Covenant Relationship (Peabody, MA: Hendrickson 2006).

Chrostowski, W., Między Synagoga a Kościołem. Dzieje św. Pawła (Kraków: Wydawnictwo „M” - Ząbki: Apostolicum 2015).

Collins, R.F., These Things Have Been Written. Studies on the Fourth Gospel (Louvain Theological and Pastoral Monographs 2; Louvain: Peeters - Grand Rapids, MI: Eerdmans 1990). 


\section{ZBIGNIEW GROCHOWSKI}

Coulot, C., Jésus et le disciple. Étude sur l'autorité messianique de Jésus (Études bibliques. Nouvelle Série 8, Paris: Gabalda 1987).

Crimella, M., Marta, Marta! Quattro esempi di "triangolo drammatico" nel "grande viaggio di Luca” (Studi e Ricerche. Sezione biblica; Assisi: Cittadella 2009).

Crimella, M., „Dal maestro alle comunità. Le comunità di Marco, Luca e Giovanni”, Parola Spirito e Vita 61 (2010) 149-159.

Culpepper, R.A., Anatomy of the Fourth Gospel. A Study in Literary Design (Philadelphia, PA: Fortress 1983).

Culpepper, R.A., „Nicodemus: The Travail of New Birth”, Character Studies in the Fourth Gospel. Narrative Approaches to Seventy Figures in John (ed. S.A. Hunt - D.F. Tolmie - R. Zimmermann) (Wissenschaftliche Untersuchungen zum Neuen Testament 2/314; Tübingen: Mohr Siebeck 2013) 249-259.

Daise, M.A., Feasts in John. Jewish Festivals and Jesus' "Hour" in the Fourth Gospel (Wissenschaftliche Untersuchungen zum Neuen Testament 2/229; Tübingen: Mohr Siebeck 2007).

Destro, A. - Pesce, M., Come nasce una religione. Antropologia ed esegesi del vangelo di Giovanni (Percorsi) (Roma: Laterza 2000).

Dietzfelbinger, C., Das Evangelium nach Johannes, wyd. 2 (Zürich: Theologischer Verlag 2004) II.

Draper, J.A., „What Did Isaiah See? Angelic Theophany in the Tomb in John 20:11-18”, Neotestamentica 36 (2002) 63-76.

Dschulnigg, P., Jesus begegnen. Personen und ihre Bedeutung im Johannesevangelium (Theologie 30; Münster - Hamburg: LIT 2000).

Dubisz, S. (red.), Wielki słownik języka polskiego. II. H-N (Warszawa: PWN 2018).

Fabris, R., Giovanni. Traduzione e commento, wyd. 2 (Roma: Borla 2003).

Ferraro, G., L'"ora” di Cristo nel Quarto Vangelo (Aloisiana 10; Roma: Herder 1974).

Ferraro, G., „Cristo di fronte alla sua «ora»”, Parole di Vita 29 (1984) 196-208.

Ferraro, G., „La terminologia temporale (l'«ora» e il «giorno» di Cristo) nel commento di Origene al quarto vangelo", Orientalia Christiana Periodica 60 (1994) 363-398.

Ferraro, G., Lo Spirito e l'“ora" di Cristo. L'esegesi di San Tommaso d'Aquino sul Quarto Vangelo (Città del Vaticano: Libreria Editrice Vaticana 1996).

Feuillet, A., „L'heure de Jésus et le signe de Cana. Contribution a l'étude de la structure du quatrième évangile", Ephemerides Theologicae Lovanienses 36 (1960) 5-22.

Filtvedt, O.J., „Revisiting Nicodemus's Question in John 3:9”, The Journal of Theological Studies 70 (2019) 110-140.

Flusser, D., „The Jewish-Christian Schism (Part I/II)”, Judaism and the Origins of Christianity (red. D. Flusser) (Jerusalem: Magnes 1988) 617-634, 635-644.

Flusser, D., „The Isaiah Pesher and the Notion of Twelve Apostles in the Early Church”, Judaism of the Second Temple Period. I. Qumran and Apocalypticism (red. D. Flusser) (Grand Rapids, MI: Eerdmans - Jerusalem: The Hebrew University Magnes Press - Jerusalem Perspective 2007) 305-326.

Galizzi, M., „È giunta l'ora che sia glorificato il figlio dell'uomo (Gv 12,23)”, Parole di Vita 29 (1984) 216-225.

Gloer, W.H., „ "Come and see»: Disciples and Discipleship in the Fourth Gospel”, Perspectives on John. Methods and Interpretation in the Fourth Gospel (red. R.B. Sloan - M.C. Parson) 


\section{GODZINA UCZNIÓW JEZUSA (J 16,32; 18-19) OKAZJĄ DO OBJAWIANIA SIĘ MISTRZA}

(National Association of Baptist Professors of Religion Special Studies Series 11; Lewiston, ME - Queenston - Lampeter: Mellen 1993) 269-301.

de Goedt, M., „Un Schème de Révélation dans le Quatrième Évangile”, New Testament Studies 8 (1962) 142-150.

Grochowski, Z., „I discepoli di Gesù nell'ora della prova (Gv 18-19) come luogo di rivelazione del Maestro", The Biblical Annals 3/1 (2013) 67-92.

Grochowski, Z., Il discepolo di Gesù nell'ora della prova (Gv 18-19), luogo di rivelazione del Maestro (Studia Biblica Lublinensia 13; Lublin: Wydawnictwo KUL 2015).

Grochowski, Z., „Kogut w Biblii z uwzględnieniem jego funkcji narracyjnej pełnionej w Ewangeliach”, Verbum Vitae 32 (2017) 255-284.

Grochowski, Z., „Cinque discepoli, radunati ai piedi della croce, accompagnano Gesù morente come il vero e autentico Maestro (Gv 19,24h-27)", Studia Ełckie 21/1 (2019) 11-26.

Grochowski, Z., „Dobry Pasterz, pojmany w Ogrójcu, daje życie swoim uczniom (J 10,1-18; 18,1-14)", Idźcie i głoście nowe życie w Chrystusie (red. Z. Grochowski - J. Kręcidło W. Linke) (Warszawa: Wydawnictwo Naukowe UKSW 2019) 141-176.

Grochowski, Z., „Nicodemus. A Disciple Liberated by the Cross of the Christ from the Darkness of Fear and Disbelief”, The Biblical Annals 10/4 (2020) 637-676.

Gryglewicz, F. - Mędala, S. - Chmiel, J., „Tradycja św. Jana”, Wstęp do Nowego Testamentu (red. R. Rubinkiewicz) (Poznań: Pallotinum 1996) 447-538.

Hanimann, J., „A propos de «l'Heure de Jésus» dans le quatrième évangile”, Nouvelle Revue Théologique 98 (1976) 544-546.

Hare, D.R.A., The Theme of Jewish Persecution of Christians in the Gospel According to St. Matthew (Society for New Testament Studies Monograph Series 6; Cambridge: University Press 2005).

Heil, J.P., Blood and Water. The Death and Resurrection of Jesus in John 18-21 (Catholic Biblical Quarterly Monograph Series 27; Washington, DC: Catholic Biblical Association of America 1995).

Hendriksen, W., Exposition of the Gospel According to John. Two Volumes Complete in One, wyd. 20 (New Testament Commentary 4; Grand Rapids, MI: Baker Academic 2007).

Horbury, W., „The Benediction of the Minim and Early Jewish-Christian Controversy”, Journal of Tamil Studies 33 (1982) 19-61.

Horbury, W., „Early Christians on synagogue prayer and imprecation”, Tolerance and Intolerance in Early Judaism and Christianity (red. G.N. Stanton - G.G. Stroumsa) (Cambridge: University Press 1998) 296-317.

van der Horst, P.W., „The Birkat ha-Minim in Recent Research (1993)”, Hellenism - Judaism Christianity. Essays on Their Interaction (red. P.W. van der Horst) (Contribution to Biblical Exegesis and Theology 8; Kampen: Kok Pharos 1994) 99-111.

Jacobs, A.S., "Jews and Christians”, The Oxford Handbook of Early Christian Studies (red. S.A. Harvey - D.G. Hunter) (Oxford: Oxford University Press 2008) 169-185.

de Jonge, M., Jesus. Stranger from Heaven and Son of God. Jesus Christ and the Christians in Johannine Perspective (Society of Biblical Literature Sources for Biblical Study 11; Montana, MT: Scholars Press 1977).

Katz, S.T., „Issues in the Separation of Judaism and Christianity after 70 C.E.: A Reconsideration", Journal of Biblical Literature 103 (1984) 43-76. 


\section{ZBIGNIEW GROCHOWSKI}

Kimelman, R., „Birkat Ha-Minim and the Lack of Evidence for an Anti-Christian Jewish Prayer in Late Antiquity", Jewish and Christian Self-Definition. II. Aspects of Judaism in the Graeco-Roman Period (red. E.P. Sanders - A.I. Baumgarten - A. Mendelson) (Philadelphia, PA: Fortress 1981) 226-244.

Klink III, E.W., The Sheep of the Fold. The Audience and Origin of the Gospel of John (Society for New Testament Studies Monograph Series 141; Cambridge - New York: Cambridge University Press 2007).

Kl'uska, B., Uczeń ikona Chrystusa. Studium egzegetyczno-teologiczne Mowy Pożegnalnej J 13,31-16,33 (Studia Biblica Lublinensia 3; Lublin: Wydawnictwo KUL 2007).

Koester, C.R., „Theological Complexity and the Characterisation of Nicodemus in John's Gospel", Characters and Characterisation in the Gospel of John (red. C.W. Skinner) (London: Clark 2013) 165-181.

Köstenberger, A.J., „Jesus as Rabbi in the Fourth Gospel”, Bulletin for Biblical Research 8 (1998) 97-128.

Köstenberger, A.J., The Mission of Jesus and the Disciples According to the Fourth Gospel. With Implications for the Fourth Gospel's Purpose and the Mission of the Contemporary Church (Grand Rapids, MI: Eerdmans 1998).

Kręcidło, J., „Tożsamość Umiłowanego Ucznia w czwartej Ewangelii”, Collectanea Theologica 78/3 (2008) 45-58.

Kręcidło, J., Honor $i$ wstyd w interpretacji Ewangelii. Szkice z egzegezy antropologicznokulturowej (Lingua Sacra. Monografie 1; Warszawa: Verbinum 2013).

Kubiś, A., „Zechariah 6:12-13 as the Referent of $\gamma \rho a \varphi \eta ́$ in John 2:22 and 20:9. A Contribution to Johannine Temple-Christology", The Biblical Annals 2 (2012) 153-194.

Kubiś, A., „Rhetorical Syncrisis in the Johannine Presentation of Jesus and Peter”, The Biblical Annals 7/4 (2017) 487-529.

Lausberg, H., Retoryka literacka. Podstawy wiedzy o literaturze (tł., red., wstęp A. Gorzkowski) (Bydgoszcz: Homini 2002).

Lieu, J., „Temple and Synagogue in John”, New Testament Studies 45 (1999) 51-69.

Lincoln, A.T., The Gospel According to Saint John, wyd. 2 (Black's New Testament Commentary 4; Peabody, MA: Hendrickson 2006).

Manns, F., „Lévangile de Jean, réponse chrétienne aux décisions de Jabne”, Studii Biblici Franciscani Liber Annuus 30 (1980) 47-92.

Manns, F., Ecce Homo. Una lettura ebraica dei Vangeli (Torino: Lindau 2011).

Manns, F., „Encore une fois «Jésus et le disciple»", Didascalia. Lisbôa 41 (2011) 29-52.

Maranesi, P., La verità di Nicodemo. Racconto evangelico di un cammino di fede (Assisi: Cittadella Editrice 2019).

Marchadour, A., I personaggi del Vangelo di Giovanni. Specchio per una cristologia narrativa (tł. R. Pusceddu) (Bologna: Dehoniane 2007).

Marguerat, D. - Bourquin, Y., Per leggere i racconti biblici. La Bibbia si racconta. Iniziazione all'analisi narrativa (tł. M. Zappella) (Roma: Borla 2001).

Mariano, C., Tetelestai. Il significato della morte di Gesù alla luce del compimento della Scrittura in Gv 19,16b-37 (Quaderni della Rivista di scienze religiose 14; Roma: Viverein 2010).

Martín-Moreno, J.M., Personajes del Cuarto Evangelio (Biblioteca de Teología Comillas 7; Madrid: Universidad Pontificia Comillas 2002). 


\section{GODZINA UCZNIÓW JEZUSA (J 16,32; 18-19) OKAZJĄ DO OBJAWIANIA SIĘ MISTRZA}

Mateos, J. - Barreto, J., El Evangelio de Juan. Análisis lingüístico y comentario exégetico (Lectura del Nuevo Testamento 4; Madrid: Cristiandad 1979).

Matera, F.J., „Jesus before Annas. John 18,13-14.19-24”, Ephemerides Theologicae Lovanienses 66 (1990) 38-55.

Mędala, S., Ewangelia według świętego Jana. II. Rozdziały 13-21. Wstęp, przekład z oryginału, komentarz (Nowy Komentarz Biblijny. Nowy Testament 4/2; Częstochowa: Edycja Świętego Pawła 2010).

Moloney, F.J., „La preghiera dell'ora di Gesù (Gv 17)”, Parola Spirito e Vita 3 (1981) 156-167.

Montanari, F., Vocabolario della lingua greca (Torino: Loescher 1995).

Moreno, R., „El discípulo de Jesucristo, según el evangelio de S. Juan”, Estudios Biblicos 30 (1971) 269-311.

Morris, L., The Gospel According to John. Revised Edition (New International Commentary on the New Testament; Grand Rapids, MI: Eerdmans 1995).

Morrison, C.D., „The «Hour of Distress» in Targum Neofiti and the «Hour» in the Gospel of John", Catholic Biblical Quarterly 67 (2005) 590-603.

Neirynck, F., „The «Other Disciple» in Jn 18,15-16”, Ephemerides Theologicae Lovanienses 51 (1975) 113-141.

Neirynck, F., „L’epanalepsis et la critique littéraire. À propos de l'Évangile de Jean”, Ephemerides Theologicae Lovanienses 56 (1980) 303-338.

O'Day, G.R., Revelation in the Fourth Gospel. Narrative Mode and Theological Claim (Philadelphia, PA: Fortress 1986).

Pesce, M., „Discepolato gesuano e discepolato rabbinico. Problemi e prospettive della comparazione", Religion (Vorkonstantinisches Christentum: Leben und Umwelt Jesu; Neues Testament [Kanonische Schriften und Apokryphen]) (red. W. Haase) (Aufstieg und Niedergang der römischen Welt 25/1; Berlin - New York, NY: De Gruyter 1982) 351-389.

Pierri, R. - GrochowskiZ., „Una portinaia non ostile”, Collectanea Christiana Orientalia 8(2011)229-235.

de La Potterie, I., La passion de Jésus selon lévangile de Jean. Texte et Esprit (Lire la Bible 73; Paris: Cerf 1986).

Powell, M.A., What Is Narrative Criticism. A New Approach to the Bible (London: SPCK1993).

du Rand, J.A., „Perspectives on Johannine Discipleship According to the Farewell Discourses”, Neotestamentica 25 (1991) 311-325.

Resseguie, J.L., The Strange Gospel. Narrative Design and Point of View in John (Biblical Interpretation 56; Leiden - Boston - Köln: Brill 2001).

Riesner, R., Jesus als Lehrer. Eine Untersuchung zum Ursprung der Evangelien-Überlieferung, wyd. 2 (Wissenschaftliche Untersuchungen zum Neuen Testament 2/7; Tübingen: Mohr Siebeck 1984).

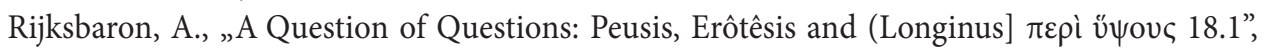
Mnemosyne, Fourth Series 56 (2003) 733-737.

Rosik, M., „Nazarejczycy czy heretycy? W kwestii Birkat ha-minim”, Więcej szczęścia jest w dawaniu aniżeli w braniu. Księga Pamiątkowa dla Księdza Profesora Waldemara Chrostowskiego w 60. rocznice urodzin (red. B. Strzałkowska) (Warszawa: Stowarzyszenie Biblistów Polskich 2011) III, 1275-1288.

Rosik, M., Kościół a Synagoga (30 -313 po Chr.). Na rozdrożu (Wrocław: Chronicon 2016). 


\section{ZBIGNIEW GROCHOWSKI}

Sabbe, M., „The Arrest of Jesus in Jn 18,1-11 and its Relation to the Synoptic Gospels. A Critical Evaluation of A. Dauer's Hypothesis", L'Évangile de Jean. Sources, rédaction, théologie (red. M. de Jonge) (Bibliotheca Ephemeridum theologicarum Lovaniensium 44; Gembloux: Duculot - Leuven: Leuven University Press 1977) 203-234.

Safrai, C., "Jesus and His Disciples: The Beginnings of Their Organization”, Immanuel 24 (1990) 95-108.

Sanders, J.N. - Mastin, B.A., A Commentary on the Gospel According to St. John (Harper's New Testament Commentaries; Peabody, MA: Hendrickson 1988).

Schnackenburg, R., Das erste Wunder Jesu (Joh. 2,1-11) (Freiburg: Herder 1951).

Schnackenburg, R., „Jünger, Gemeinde, Kirche im Johannesevangelium”, Das Johannesevangelium. III. Kommentar zu Kap. 13-21 (red. R. Schnackenburg) (Herder Theologisches Kommentar zum Neuen Testament 4; Freiburg - Basel - Wien: Herder 1975) 231-245.

Schoeps, H.-J., Jewish Christianity. Factional Disputes in the Early Church (Philadelphia PA: Fortress 1969).

Segalla, G., Evangelo e vangeli. Quattro evangelisti, quattro vangeli, quattro destinatari (La Bibbia nella storia 10; Bologna: Dehoniane 1993).

Segovia, F.F., „ «Peace I leave with You; My Peace I give to You»: Discipleship in the Fourth Gospel", Discipleship in the New Testament (red. F.F. Segovia) (Philadelphia, PA: Fortress 1985) 76-102.

Senior, D., „The Death of Jesus and the Meaning of the Discipleship”, The Death of Jesus in Early Christianity (red. J.T. Carroll et al.) (Peabody, MA: Hendrickson 1995) 234-255.

Serra, S., Contributi dellantica letteratura giudaica per l'esegesi di Giovanni 2,1-12 e 19,25-27 (Scripta Pontificiae Facultatis Theologicae Marianum 31; Roma: Herder 1977).

Sigal, P., „An Inquiry into Aspects of Judaism in Justin's Dialogue with Trypho”, Abr-Nahrain 18 (1979) 74-100.

Siker-Gieseler, J.S., „Disciples and Discipleship in the Fourth Gospel: A Canonical Approach”, Studia Biblica et Theologica 10 (1980) 199-227.

Sikora, A.R., „Uczeń, którego Jezus miłował, świadkiem i nauczycielem wiary”, Poznańskie Studia Teologiczne 26 (2012) 87-105.

Sikora, A.R., „Zobaczył i uwierzył” (J 20,8). Droga wiary umiłowanego ucznia Jezusa w ujęciu egzegezy teologicznej (Studia i Materiały 150; Poznań: Wydawnictwo Uniwersytetu Adama Mickiewicza 2012).

Ska, J.L., „Our Fathers Have Told Us”. Introduction to the Analysis of Hebrew Narratives (Subsidia Biblica 13; Roma: Pontificio Istituto Biblico 2000).

Smyth, H.W., Greek Grammar (Cambridge, MA: Harvard University Press 1984).

Szczepański, W., Bóg - Człowiek w opisie Ewangelistów (Kraków: Wydawnictwo Księży Jezuitów 1924).

Teppler, Y.Y., Birkat haMinim. Jews and Christians in Conflict in the Ancient World (Texte und Studien zum Antiken Judentum 120; Tübingen: Mohr Siebeck 2007).

Van der Merwe, D.G., „Towards a Theological Understanding of Johannine Discipleship”, Neotestamentica 31 (1997) 339-359.

Vignolo, R., Personaggi del Quarto Vangelo. Figure della fede in San Giovanni, wyd. 2 (Milano: Glossa 2006). 


\section{GODZINA UCZNIÓW JEZUSA (J 16,32; 18-19) OKAZJĄ DO OBJAWIANIA SIĘ MISTRZA}

Viteau J., Étude sur le grec du Nouveau Testament. Le verbe. Syntaxe des propositions (Paris: Librairie Émile Bouillon 1893).

von Wahlde, U.C., The Gospel and Letters of John. II. Commentary on the Gospel of John (Eerdmans Critical Commentary; Grand Rapids, MI - Cambridge: Eerdmans 2010).

Whitenton, M.R., „The Dissembler of John 3: A Cognitive and Rhetorical Approach to the Characterization of Nicodemus", Journal of Biblical Studies 135 (2016) 141-158.

Whitenton, M.R., Configuring Nicodemus. An Interdisciplinary Approach to Complex Characterization (Library of New Testament Studies 549; London: Clark 2019).

Wilson, S.G., Related Strangers. Jews and Christians 70-170 C.E. (Minneapolis, MN: Fortress 1995).

Witczyk, H., „Historia w ewangelicznych świadectwach o Męce i Śmierci Jezusa”, Jezus i Ewangelie w ogniu dyskusji. Od H. Reimarusa do T. Polaka (red. J. Kudasiewicz - H. Witczyk) (Biblioteka „Verbum Vitae” 2; Kielce: Verbum 2011) 225-288.

Wróbel, M.S., „Znaczenie formuły Birkat ha-Minim w procesie rozdziału Synagogi od Kościoła", Collectanea Theologica 78/2 (2008) 65-80.

Zevini, G., „L'«ora» di Gesù nel vangelo di Giovanni”, Parole Spirito e Vita 36 (1997) 153-169.

Zevini, G., „L'«ora» di Gesù nel Vangelo di Giovanni alla luce dell' «ora storica» della Gerusalemme d'oggi", Ecce ascendimus Jerosolyman (Lc 18,31). Miscellanea di studi offerti per il $75^{\circ}$ dello Studentato Teologico Salesiano in Terra Santa e il Centenario dell'Ispettoria salesiana del Medio Oriente (red. F. Mosetto) (Biblioteca di Scenze Religiose 184; Roma: Libreria Ateneo Salesiano 2003) 105-123.

Zlotnick, D. - Kutscher, E.Y., The Tractate "Mourning". Sémahot. Regulations Relating to Death, Burial, and Mourning. Translated from the Hebrew. With Introduction and Notes by Dov Zlotnick. With Hebrew Text Vocalized by E. Y. Kutscher (Yale Judaica Series 17; New Haven, CT: Yale University Press 1966).

Zumstein, J., Lévangile selon saint Jean (13-21) (Commentaire du Nouveau Testament 4b; Genève: Labor et Fides 2007). 
